Rafael Elias Teixeira

\title{
Encanto e entorpecimento: um caminhar por entre imagens contemporâneas
}

Dissertação apresentada ao Programa de Pós-Graduação da Escola de Comunicações e Artes da Universidade de São Paulo, como exigência parcial para obtenção do título de Mestre em Ciências da Comunicação. Área de concentração: Teoria e Pesquisa em Comunicação.

Orientador: Prof. Dr. Ciro Juvenal Rodrigues Marcondes Filho

São Paulo

2010 
UNIVERSIDADE DE SÃO PAULO

ESCOLA DE COMUNICAÇÕES E ARTES

Dissertação apresentada ao Programa de Pós-Graduação da Escola de Comunicações e Artes da Universidade de São Paulo, como exigência parcial para obtenção do título de Mestre em Ciências da Comunicação.

Programa: Ciências da Comunicação

Área: Teoria e Pesquisa em Comunicação

Orientador: Prof. Dr. Ciro Juvenal Rodrigues Marcondes Filho

BANCA EXAMINADORA

Ciro Juvenal Rodrigues Marcondes Filho (orientador) 


\section{Resumo}

A presente dissertação apresenta uma tentativa de compreender a relação entre o homem atual e as imagens que o rodeiam. Para tanto, o pesquisador colocou-se como um instrumento da pesquisa, ao participar ativamento do processo e ao descrever suas impressões com envolvimento. A experiência consistiu em assistir aleatoriamente vídeos disponíveis na internet por um período determinado, a fim de reproduzir uma situação cotidiana para boa parte da população mundial. A partir disso, produziu-se um relato com a descrição das sensações e, por meio dele, construiu-se uma série de apontamentos e inferências teóricas, entrelaçando-o às teorias atuais sobre a imagem e seus efeitos sobre o indivíduo.

O conteúdo foi disposto em três partes: a primeira consiste em apresentar e discutir o conceito de comunicação como Acontecimento, utilizado no trabalho, e o metáporo, o quase-método, utilizado na pesquisa; a segunda parte apresenta as vertentes de estudos da imagem, utilizadas como base para a discussão, e alguns princípios da percepção; e a terceira e última parte trata da impossibilidade de haver comunicação com os vídeos da forma como são disponibilizados, os mecanismos de encanto e entorpecimento das imagens contemporâneas, e um arremate geral da discussão, apresentando as possíveis consequências do excesso de imagens para o ser humano atual.

Palavras-chave: comunicação; imagem; Acontecimento; metáporo; contemporaneidade. 


\begin{abstract}
This work presents an attempt to understand the relationship between modern man and the images that surround him. For this, the researcher has established himself as a research instrument, to participate actively in the process and describe his impressions with involvement. The experience consisted of watching random videos available on the internet for a specified period in order to reproduce an everyday situation of most of the world population. From this, it was produced a report describing the sensations, and through it, built a series of notes and theoretical inferences, weaving the existing theories on the image and its effects on the individual.

The contents were ordered in three parts: the first is to present and discuss the concept of communication as Happening, used in this work, and metáporo, the quasi-method used in the research; the second part presents the aspects of image studies, used as a basis for discussion, and some principles of perception; and the third and final part deals with the impossibility of communication with the videos in the way they are made available, the mechanisms of delight and numbness of contemporary images, and an overall finish of the discussion, presenting the possible consequences of excessive images for humans today.
\end{abstract}

Key words: communication; image; Happening; metáporo; contemporaneity. 


\section{Agradecimentos}

Ao final deste trabalho, há algumas pessoas para as quais devo meu agradecimento, pois sem elas, nada disso seria possível.

Meu orientador, Ciro Marcondes Filho, que nunca se negou a partilhar, com entusiasmo e dedicação, seu conhecimento com um pesquisador em seus primeiros passos na vida acadêmica.

Meus pais, meus irmãos e meu avô, figuras centrais em minha vida que, mesmo estando distantes fisicamente, estão e estarão sempre presentes, dando-me todo o apoio necessário.

Meus queridos amigos, minha segunda família, que estão sempre dispostos a me dar o apoio necessário nos momentos mais difícies e a aproveitar os momentos felizes, especialmente Claudia Agnelli, Diego Rodrigues, Gisele Quirino, Lúcia Peres, Mariana Keller, Naiara Raggiotti e Tereza Kikuchi. E Márcio Ito, companheiro para todas as horas.

Agradeço, com carinho, a todos. 
À minha familia, dada e escolbida. 
Pensar, pensar

"Acho que na sociedade atual nos falta filosofia. Filosofia como espaço, lugar, método de reflexão, que pode não ter um objetivo determinado, como a ciência, que avança para satisfazer objetivos. Falta-nos reflexão, pensar, precisamos do trabalho de pensar, e parece-me que, sem ideias, não vamos a parte nenhuma."

José Saramago. Revista do Expresso, Portugal (entrevista), 11.10.2008 (Publicado no blog Outros cadernos de Saramago em 18.06.2010, dia do falecimento do escritor) 


\section{Sumário}

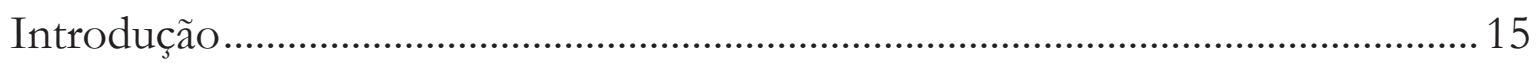

Caminhar por entre imagens 1 ............................................................................ 19

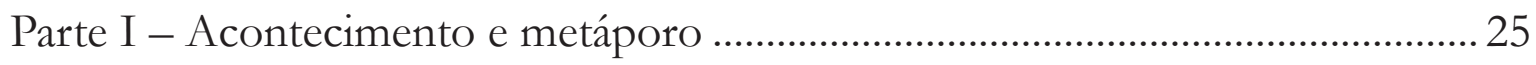

Capítulo 1: A comunicação como Acontecimento..................................................... 27

Capítulo 2: Caminho sem trilhas ................................................................................ 31

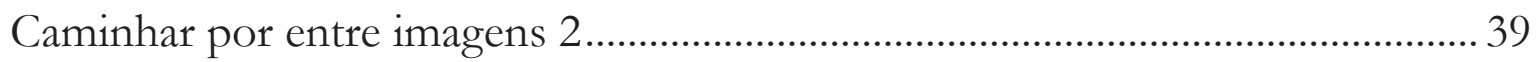

Parte II - As imagens e a percepção.......................................................................... 45

Capítulo 1: Vertentes de estudos da imagem na contemporaneidade ................... 47

Capítulo 2: Tópicos a respeito da percepção ………………………………………... 59

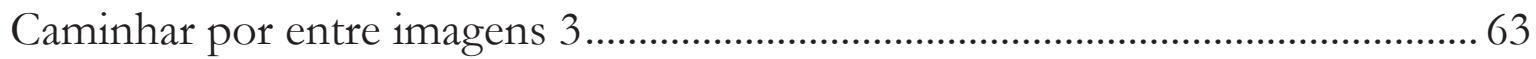

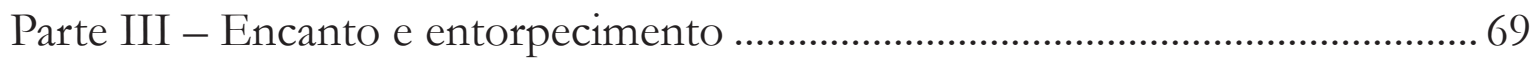

Capítulo 1: Da impossibilidade da comunicação ....................................................... 71 


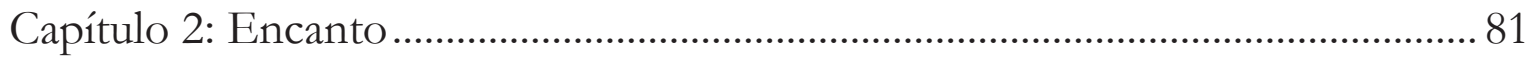

Capítulo 3: Entorpecimento ..................................................................................... 91

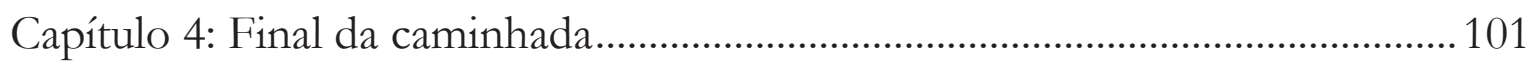

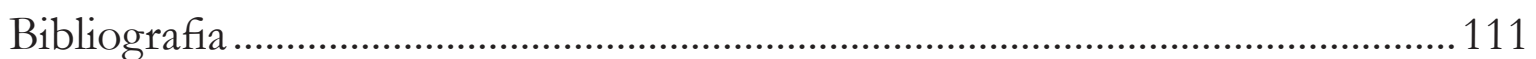




\section{Introdução}

$\mathrm{Na}$ contemporaneidade, o ser humano vive imerso em imagens. Tal afirmação pode parecer óbvia, no entanto em tal obviedade reside justamente a razão para se voltar a atenção a ela e refletir um pouco mais a seu respeito. Ao exprimir uma condição, um estado, a sentença em questão tenta expressar, por meio de palavras em um código escrito, uma sensação que para muitos passa despercebida, como se de fato, devido a sua clareza, não merecesse qualquer tipo de reflexão. Talvez com um pouco mais de insistência, possa-se alcançar a verdadeira dimensão do que está escrito acima.

A sentença inicia-se com uma delimitação temporal. Entre todos os milhares de anos da odisseia humana ou mesmo entre todo o insondável tempo do Cosmos, escolhe-se o tempo atual, a época a transcorrer na atualidade. A escolha não é gratuita: ela implica, em si, a tentativa de se capturar o momento em andamento, o presente, sem se utilizar de mecanismos de rememoração histórica; trata-se do agora.

Em termos históricos, o termo contemporaneidade remete à época contemporânea, ou seja, ao período pós-revoluções burguesas, cristalizadas didaticamente na Revolução Francesa de 1789. Também está ligado às revoluções das técnicas de produção industrial iniciadas com as máquinas a vapor e, por extensão, às demais revoluções tecnológicas subsequentes. Em poucas palavras, é a época histórica em que a técnica assume grande importância na equação social.

Em meio a esse ambiente tecnológico, está o ser humano. É inegável que a condição humana na contemporaneidade é singular a de qualquer outro período histórico, pois os avanços 
dessa área do conhecimento no início do século XXI não podiam ser sequer imaginados nem pela melhor literatura de ficção científica de outrora. Como consequência, o grau de envolvimento e dependência do homem em relação à técnica é tão intenso que por vezes não é possível refletir sobre a situação. Parece-nos que a técnica somente traz bons frutos e isso basta para nós. Não obstante os benefícios advindos com o desenvolvimento, há também as consequências, como em toda relação, e é sobre tal fato que se debruça este estudo.

A tecnologia nos trouxe a possibilidade de acessar dados de qualquer parte do planeta e sobre qualquer assunto. Dessa enorme quantidade de dados acessíveis, boa parte é composta por imagens. O conhecimento humano, que sempre se baseou na escrita como principal forma de disseminação, torna-se cada vez mais imagético. Com o advento dos meios de produção e distribuição em massa de dados, sobretudo na segunda metade do século passado, deu-se a virada imagética, momento em que a imagem recuperou o status predominante na cultura, do qual ela já gozara nos períodos pré-escrita. Bem como no período pré-histórico, a imagem recuperou seu componente mágico - antes como forma de materializar o sagrado, no caso das imagens sacras, agora como portal capaz de transportar o indivíduo para outras vivências, no caso das imagens cada vez mais ricas em detalhes. E, com essa aura mágica, potencializada por sua aparência de real, fecha-se em si mesma, tornando-se uma verdade incontestável.

A motivação deste estudo é justamente lançar questões a respeito da relação homem e imagens, no contexto da sociedade tecnológica atual. Partindo-se do princípio de que a imagem, através da tecnologia, está presente no cotidiano dos bilhões de seres humanos ao redor do planeta, é necessária uma reflexão a respeito da natureza de tal relação. O objeto, portanto, não é homem e nem mesmo as imagens, mas sim o que ocorre na relação entre os componentes do processo.

Niklas Luhmann propôs que "aquilo que sabemos sobre nossa sociedade, ou mesmo sobre o mundo no qual vivemos, o sabemos pelos meios de comunicação" (LUHMANN, 2005, p. 15); de fato, pode-se nunca ter ido à China, por exemplo, mas ao pronunciar-se o nome da país, uma profusão de imagens vêm à mente, imagens produzidas e disseminadas das mais variadas formas. Essa concepção da realidade por meio das imagens tecnicamente produzidas é, no míni- 
mo, diferente daquela produzida diretamente pelo estar no mundo heideggeriano. Não se trata, portanto, de fazer um juízo de valor, mas de descrever a condição humana na atualidade.

O estudo busca repetir a experiência de se viver entre imagens, como ocorre com o homem atual, mas com um olhar voltado para as sensações que tal vivência provoca no sujeito. É uma tentativa de trazer para a discussão acadêmica uma experiência banal, mas que exatamente por sua banalidade, passa despercebida e suas consequências não são notadas.

Para atingir tal intento, delimitou-se a experiência em visualizar vídeos da internet, disponibilizados pela ferramenta YouTube. A escolha do site foi devido a sua popularidade, o que o torna o maior portal de conteúdo imagético atual, com contribuições tanto de desenvolvedores amadores quanto de reproduções de imagens originalmente produzidas para veiculação em outros meios, como a televisão e o cinema. Essa ferramenta sintetiza a questão da imagem na internet, pois apresenta uma multiplicidade tão grande que se torna difícil resistir a assistir a apenas um vídeo, levando o sujeito a gastar boa parte do seu dia para visualizar as inúmeras possibilidades propostas a partir de um primeiro ato inicial.

A ideia é a de reproduzir a experiência de quem passa horas em contato com um turbilhão de imagens disponíveis e quais as sensações que tal experiência é capaz de proporcionar. Para tanto, foi proposto assistir quatro horas ininterruptas de vídeos, sem critérios de escolhas, apenas aceitando alguma das inúmeras sugestões de próximos vídeos que a própria ferramenta apresenta. Levando-se em conta que parte significativa da população passa suas horas de trabalho conectada, como também seu tempo livre para lazer, a experiência tenta se aproximar de uma vivência cotidiana e, a partir dela, fazer inferências e relacioná-las ao arcabouço teórico desenvolvido pela área até o momento.

Com a descrição da experiência e a discussão de suas consequências, tenta-se transmitir ao leitor as mesmas sensações provenientes da vivência entre imagens. Por se tratar de um objeto intangível e somente perceptível através de seus rastros no processo, a própria estrutura do trabalho também busca uma certa vivacidade. O conteúdo é dividido em partes e cada uma é dividida em capítulos curtos, na tentativa de passar a sensação de imersão e dispersão sentida durante a visualização dos vídeos. Antes de cada parte, há a inserção do relato da experiência em si, também dividido em três para manter a sensação de interrompimento do processo. A lingua- 
gem buscou ser a mais solta e direta possível, aproximando-se em muito da linguagem cotidiano do pesquisador, na tentativa de tornar o relato o mais fiel à experiência pessoal.

Este trabalho apresenta a possibilidade de uma abordagem mais pessoal e com maior comprometimento do sujeito com a pesquisa para os estudos dos fenômenos comunicacionais. Além disso, trata-se de uma proposta de abertura para discutir a comunicação como um meio para compreendermos o presente e buscarmos alternativas para a condição humana na contemporaneidade. 


\section{Caminhar por entre imagens 1}

Coloco-me diante da tela em busca de uma experiência que me apresente algo, o qual eu não sei exatamente do que se trata, mas me interesso pela busca. A busca em si já é uma jornada sem trilhas abertas, é uma estrada rumo ao ainda não explorado. É o entrar em uma mata densa sem a intenção de desbravá-la, de torná-la mais aprazível para os costumes civilizados. Ao explorador de uma terra virgem não resta nada além de tentar dominá-la, fazer com que seus mistérios sejam compreendidos e domesticados, não oferecendo espaço para a surpresa, o inesperado. Para ele, o inesperado representa o perigo, aquilo que o ameaça tanto biologicamente, ao oferecer um risco, real ou imaginário, para sua sobrevivência, como de quebra de paradigma, pois pode ter o poder de apresentar uma outra versão de pensar, de existir, de viver. A tarefa do explorador é amoldar a nova terra aos parâmetros já conhecidos, encaixá-la no modelo que julga ser o único possível e imaginável para a sobrevivência.

De modo diverso a do explorador, minha jornada não possui um ponto final, um objetivo a ser alcançado por meio do desbravamento. O importante é o caminhar. No livre caminhar está a chave para o novo, pois através do ato em movimento é que nos chega a novidade. O caminhar é uma eterna potencialidade, um leque de virtualidades à espera de serem realizadas. O movimento proporciona o atrito entre os corpos. Os esbarrões que o desbravador de trilhas sofre serão as marcas da caminhada, as arranhaduras em sua pele serão como uma prova inconstestável do vivido, do experimentado. Assim como o desbravador arranhado pela mata fechada, não se pode terminar uma jornada sem marcas, sem rasgões em nossa superfície. A superfície é coesa, 
fechada, e os arranhões chegam como que para provar que não se é totalmente fechado, é possível, mesmo à força, provocar fissuras, forçar o contato, expor o que está dentro, protegido, ao desconhecido de fora. As feridas expandem os poros, tornam descontínuo o tecido que outrora parecia impermeável. Elas são a prova indelével da experiência: não se sai de uma experimentação da mesma forma com que se entrou. Experimentar nos obriga a mudar, torna-nos outro, sendo o mesmo corpo e a mesma mente. A mudança ocorre mesmo que a contragosto, mesmo que despercebida. Já se é outro.

A tela do computador é como um portal para uma outra dimensão. Através dela, tenho contato com outros mundos, sou transportado para outros locais. No entanto, sigo inerte. Essa é uma jornada estanque, um movimento estático. Caminhar por entre imagens é um caminhar com os sentidos, é um mergulho de cabeça e com a cabeça. É uma jornada sem uma mudança espacial. No entanto, por mais que se tente um distanciamento, as imagens fazem com que você se misture com elas ao ponto de não mais existir barreiras entre você e elas. Por mais que se tente um distanciamento, elas carregam você para essa jornada e, como guias ao contrário, fazem com que você se perca em seus muitos caminhos.

A internet proporciona uma experiência singular, pois nela estão contidos diversos meios; ela é um grande centro aglutinador de meios. Por meio dela, é possível ter acesso às mais diversas imagens, todas concentradas em um mesmo aparato. As imagens estão ali, à espera de serem vasculhadas, percorridas e exploradas. O jogo é justamente este: temos a intenção, e a pretensão, de sermos os mandantes desse jogo, entramos nele com a certeza de que temos controle da situação. Achamos que podemos saber com exatidão seu início e seu fim, determinar suas regras e definir os lances. O que nos escapa é justamente a natureza do jogo, pois não se trata de um jogo solipsista; é, em verdade, uma via de mão dupla, uma interação em que nem sempre a consciência é o principal ator da cena. O interessante é jogar, deixar-se levar pela situação e tentar sentir o que realmente acontece.

O meu interesse é esse Acontecimento. O Acontecimento se dá justamente no atrito, na exposição de corpos a uma corrente. É algo que nos transpassa, que nos atravessa e, dessa forma, deixa marcas. São as marcas da transformação, da mudança, indícios de que houve qualquer 
situação de diferente ali e que foi capaz de mudar as estruturas. O Acontecimento é a prova de que nada é permanente e imutável, de que tudo está em movimento e que só nos resta participar dele, ampliar nosso arcabouço de experiências justamente por meio desse embate do aparentemente estático com o que força o movimento. Temos a sensação de sermos estáticos, de já estarmos prontos; nosso corpo nos dá essa sensação. Talvez por isso pensamos que tudo que está ao nosso entorno também o está. Com esse tipo de certeza, perdemos a oportunidade de vislumbrarmos o que há de interessante, de sentirmos a força criadora se movimentando e forçando que tudo também se movimente. Sem nos permitirmos participar dessa dança, não teremos acesso ao que há de inovador e de transformador.

Para poder sentir esse movimento, coloco-me à disposição do Acontecimento. Abro-me e permito que as imagens me guiem e me façam percorrer os caminhos criados a cada instante pelo próprio ato de percorrer. Sou como um iniciante deixando que o parceiro o guie nos movimentos da dança. Não espero nada, apenas me deixo levar pelas sensações, com o propósito somente de captar tudo o que for possível. É nesse sentido a abertura: é estar atento para que o Acontecimento se dê.

Parto do princípio de que há algo de diferente na relação entre o ser humano e as imagens. Por diversas vezes em que estive em contato direto e prolongado com as imagens, sentia que algo acontecia. Meu interesse só aumentou com o passar dos anos e com a evolução dos meios, já que com a internet a oferta e as opções de imagens são infinitas. É uma sensação estranha, mas estranha por ser nova, diferente de outras experiências. Algo me atraía nessa relação e simultaneamente me afastava, com todo o poder que só a novidade pode ter: seduz e assusta ao mesmo tempo. Sempre considerei essa relação algo diferente e desafiador, por isso a tentativa de entender o que ocorre.

Por se tratar de um fenômeno fugidio, não se presta à uma análise clássica. Ele está no campo do invisível, das sensações, do jogo de forças, do Acontecimento. O Acontecimento não pode ser visto, medido e esquartejado para olharmos suas vísceras. Não pode ser fotografado ou catalogado. Ele é um todo e assim deve ser tratado. Devo captá-lo com meus sentidos e repercuti-lo em meu corpo. Devo pulsar conforme seu movimento e não me distanciar dele, para olhá-lo 
ao longe. A experiência só pode ser completa com a entegra total, de uma forma em que eu me dilua no próprio Acontecimento. Em algum ponto, e por um ínfimo instante, não haverá mais diferença entre mim e as imagens, pois ambos estaremos tomados pela força vibrante do Acontecimento. É preciso estar alerta para buscar todas as sensações, participar dessa cena, para poder descrevê-la com a maior honestidade possível. Tudo em mim se voltará a esse intento.

Meus movimentos físicos são apenas o clicar para iniciar um novo vídeo. Não me preocupo com o conteúdo das imagens, o assunto a ser tratado, mas sim com o me deixar levar sem muita interferência minha. As escolhas estão presentes, mesmo que de uma forma não pensada. A decisão de clicar para assistir um vídeo e não todos os outros disponíveis já anuncia uma certa seleção de conteúdo. Não importa; nessa minha jornada, a busca é pela continuidade, pela exposição prolongada a essas imagens. Minha intencionalidade está voltada para percorrer mais e mais vídeos, tentando vivenciá-los em meu ser, fazendo com que eles repercutam em mim.

O atrito ao ser transpassado pelo Acontecimento deixa marcas. Como as rugas na face, tais marcas são o atestado da vivência. Vivenciar o Acontecimento também deixa seus arranhões. Não na superfície da pele, mas sim na estrutura do ser. Ao entrar em confronto com a pulsação do movimento, vivencia-se uma experiência transformadora. Algo aconteceu ali e deixou sinais. $\mathrm{O}$ Acontecimento devasta o ser, dilacera-o. Rapidamente há a recomposição, mas como um vaso quebrado e colado novamente, o ser já não é o mesmo ser: é ele e mais as marcas do ocorrido. Essa transformação muda a estrutura interna do ser e, em consequência, a participação dele no mundo. Após um Acontecimento, somos nós e mais o que foi mudado e acrescentado no processo.

As mudanças apresentadas na estrutura do ser são por si sós registros do Acontecimento. Tais registros são importantes na sua descrição, pois atestam que algo importante acorreu ali, de tamanha força que provocou uma transformação. Para descrever um fenômeno como esse, deve-se também levar em conta as mudanças provocadas por ele. Por menores que sejam, elas afetam a estrutura do ser, transformam-no em um ser aumentado. As consequências de um Acontecimento também atestam sua fugaz existência. 
Escrever é, de alguma forma, uma tentativa de apreender o mundo em um código fixo. No entanto, a apreensão do movimento é o seu homicídio, pois assim ele perde sua principal característica: a vivacidade. Essa vivacidade, essa força, dá vida ao movimento. Bem como um animal selvagem enjaulado, que em tal situação deixa de ser ele mesmo e passa a ser um arremedo do que era antes, o movimento apreendido perde todo seu encanto e passa a ser qualquer coisa que não ele mesmo. Como não busco apreender o movimento para não matá-lo, devo descrevêlo de uma forma fiel a ele. Uso o código conhecido, mas de uma forma a transpassar através dele um pouco do espírito do Acontecimento. A lingua é utilizada a esse favor, de uma forma a transpor para o leitor, também em sua composição, a vivacidade.

Coloco-me como a própria cobaia do experimento. Quero sentir em mim a força do Acontecimento. Deixo-me um pouco de lado para me transformar apenas em um ser transpassado pela energia. Estou com a mente aberta, com o desejo de me deixar envolver pela experiência e me misturar com as imagens. Faço o meu próprio caminho, sem buscar trilhas abertas, desbravando o não exprimível. Entro no campo das sensações com a intenção de senti-las por completo, de deixar que elas me atropelem e me carreguem para além do que eu possa esperar. Sei que tal experiência me trará marcas, mas também sei que elas serão a prova do vivido. 


\section{Parte I}

\section{Acontecimento e metáporo}

A área de comunicação tem se empenhado para compreender os efeitos que os diversos meios de difusão de informação causam na sociedade. Por vezes, os estudos são voltados para aplicações práticas para os meios, com vistas a transformações sociais e políticas. No entanto, pouco se conhece da comunicação em si, ou seja, do momento em que os dados vindos dos meios atingem o sujeito. Independentemente das consequências, aquele momento essencial não raro é desprezado pelos pesquisadores, que acabam por se ocupar preferencialmente das técnicas envolvidas no processo, sem se voltarem para o efeito instantâneo proporcionado pela interação sujeito e meio.

A proposta desenvolvida neste trabalho é a de vasculhar essa interação, em busca de uma compreensão maior de seu desenvolvimento. A tentativa não pressupõe uma compreensão cartesiana do fato, no sentido de análise - divisão do objeto em tantas partes quanto forem necessárias para melhor desvendá-lo -, mesmo porque o objeto em questão, a comunicação, não se presta a tal empreitada. Trata-se de um fenômeno instantâneo e passageiro, cujos vestígios são sentidos e utilizados para delimitar sua extensão.

Para melhor compreender a dimensão do objeto em questão, utiliza-se o conceito de comunicação como Acontecimento. Tal ideia coloca o fenômeno comunicacional no âmbito dos incorpóreos, instância sem materialidade, mas que pode ser sentida por meio das consequências de suas relações com os corpos ou seres. O Acontecimento comunicacional proporciona uma 
transformação no sujeito, ao forçar o pensamento e levar à criação de novas relações entre conceitos pré-existentes, dando vazão à criatividade e ao surgimento do novo.

Em se tratando de um objeto com características tão peculiares e desafiadoras, os instrumentos para melhor compreendê-lo também devem ser igualmente inovadores. Com tal intuito, utiliza-se o metáporo, um quase-método, o qual pressupõe um maior envolvimento do pesquisador com o estudo, a fim de propiciar uma relação mais próxima, sem almejar um distanciamento científico. Tenta-se, com isso, interagir com o objeto de estudo, não apenas enxergá-lo como algo distante, mas sim como uma experiência possível de ser vivenciada por qualquer sujeito no mesmo momento histórico. 


\section{Capítulo 1 A comunicação como Acontecimento}

O conceito de Acontecimento é derivado de obras de Gilles Deleuze, principalmente Lógica do sentido. Segundo o filósofo, a noção de Acontecimento surge com os estóicos, ao descreverem o incorpóreo: algo que está entre os corpos, que os anima e os energiza. Em suas próprias palavras:

Os Estóicos, por sua vez, distinguiam duas espécies de coisas: 1) Os corpos, com suas tensões, suas qualidades físicas, suas ações e paixões e os "estados de coisas" correspondentes. Estes estados de coisas, ações e paixões são determinados pelas misturas de corpos. [...] O único tempo dos corpos e estados de coisas é o presente. Pois o presente vivo é a extensão temporal que acompanha o ato, que exprime e mede a ação do agente, a paixão do paciente. [...] Não há causas e efeitos entre os corpos: todos os corpos são causas, causas uns com relação aos outros, uns para os outros. [...] 2) Todos os corpos são causas uns para os outros, uns com relação aos outros, mas de quê? São causas de certas coisas de uma natureza completamente diferente. Estes efeitos não são corpos, mas, propriamente falando, "incorporais". Não são qualidades e propriedades físicas, mas atributos lógicos e dialéticos. Não são coisas ou estados de coisas, mas acontecimentos. [...] Não são presentes vivos, mas infinitivos: Aion ilimitado, devir que se divide ao infinito em passado e em futuro, sempre se esquivando do presente. (DELEUZE, 2007, p.5-6) 
Portanto, o Acontecimento não está nos seres ou nas coisas; está nas relações. Enquanto o presente reside nos corpos, que padecem no tempo, o passado e o futuro residem como instância infinitamente divisível nos incorpóreos, resultantes das relações entre os corpos. Ele é o resultado das ações dos agentes, "não são substantivos ou adjetivos, mas verbos" (op.cit. p.5). Por ser verbo, o Acontecimento se relaciona com a ação, que transforma o ser, atribuindo-lhe um novo estado de existência. "Quando o escalpo corta a carne, o primeiro corpo produz sobre o segundo não uma propriedade nova, mas um atributo novo, o de ser cortado. $\mathrm{O}$ atributo não designa nenhuma qualidade real..., é sempre ao contrário expressa por um verbo, o que quer dizer que não é um ser, mas uma maneira de ser...”.

No Acontecimento, portanto, reside a energia transformadora, capaz de tirar os corpos de uma existência contínua e levá-los à mudança, à transformação. Nele está contida a energia da vida, as infinitas possibilidades de criação e de novas experiências. É no entre os seres e as coisas, ou seja, no campo do incorpóreo, do Acontecimento, que passa a energia capaz de criar o novo, propiciar o surgimento do inesperado.

A aplicação do conceito de Aconteciomento para pesquisas comunicacionais veio a partir dos estudos desenvolvidos pelo Núcleo de Estudos Filosóficos da Comunicação - Filocom - sediado na Escola de Comunicações e Artes da Universidade de São Paulo, no projeto de pesquisa Nova Teoria da Comunicação. A proposta é diferenciar a comunicação da sinalização e da informação. A sinalização é um processo natural dos corpos e dos seres, no qual todos emitimos sinais o tempo todo. Pode ser passiva, quando o simples fato de existir já sinaliza tal condição, como ativa, a exemplo do que fazem a imprensa, a publicidade ou mesmo os sinais de alerta em vias públicas. O sinal é apenas um ruído, uma irritação, que pode ou não passar despercebido.

No entanto, quando a sinalização é capaz de captar a atenção do sujeito, que se volta para ela e busca compreendê-la, ela passa a ser uma informação. Tal processo depende da intencionalidade do sujeito, que por meio de seu interesse busca se relacionar com aquele sinal e tirar dele algo que lhe seja útil ou mesmo que confirme suas convicções. A informação é a passagem do sinal, um mero ruído, para algo que possa ser útil ao sujeito.

1 BRÉHIER, Emile. La theorie des incorporels dans l'ancien stoicisme. Vrin, 1928, p.11-13, apud DELEUZE, 2007, p.6. 
No caso da comunicação, temos um aprofundamento do processo sinalização-informação. Trata-se do momento em que o sinal deixa de ter apenas uma característica utilitária para o sujeito e chega ao ponto de surpreendê-lo, forçá-lo a pensar. A comunicação é um fenômeno que violenta e força o pensamento. Bem como o Acontecimento, que com sua energia transforma os corpos, atribuindo-lhes qualidades antes não presentes, o Acontecimento comunicacional provoca uma transformação no ser, obrigando-o a rever suas opiniões, pensar novamente suas posições sobre diversos assuntos que antes pareciam-lhe fixas, cimentadas em sua consciência. É uma transformação na estrutura de sentidos do ser, a qual faz com que ele deixe sua posição cômoda de apenas retroalimentar suas convicções e o desafie a criar novas relações, novas conexões entre ideias. Por meio desse fenômeno, há o surgimento do novo, a capacidade criativa do sujeito reside na possibilidade de ele estar aberto para os sinais que possam lhe propiciar uma experiência mais profunda e significativa, capaz de lhe proporcionar a transformação e, assim como nos corpos, atribuir-lhe um novo atributo, uma nova qualidade.

Sob esse aspecto, a comunicação é vista como um instante transformador que força o pensamento e provoca uma mudança nos sujeitos envolvidos, sem juízo de valor. Ela não é encarada como transmissão de informações, ela não é algo concreto que se possa transportar; ela é um incorpóreo, produto de relações e em constante movimento. Ela é como um insight, um momento em que algo se torna claro e, com sua força, acaba por mudar os regimes de pensamento e de sensibilidade do sujeito. A comunicação está no processo, no durante, e pode acontecer em um diálogo interpessoal, na confrontação com um objeto de arte ou na recepção de uma notícia a partir dos meios de comunicação sociais. Ela é uma forma de apreensão sensível do mundo.

Do conceito de comunicação como Acontecimento podendo ser aplicado para relações entre os sujeitos e os objetos culturais, advém a possibilidade de aplicá-lo à questão da relação entre imagens e sujeitos. Vista por esse ângulo, tal relação pode ser investigada em sua vivacidade, como um processo que não se sabe como começa ou termina, mas que é sentido com tamanha força que obriga a uma mudança em nossas estruturas de sentidos e cria a possibilidade de novas relações entre conceitos pré-existentes.

No atual estado da sociedade tecnológica, nota-se uma presença cada vez mais constante das imagens produzidas a partir de aparatos tecnológicos no cotidiano dos seres humanos. Fo- 
tografia, cinema, televisão e vídeos pulverizados pela internet, por exemplo, tornam-se onipresentes, e é praticamente impossível pensar em algum fato que não tenha tido algum registro imagético. Constata-se que, atualmente, uma parcela considerável de informações é transmitida por meio de imagens, em movimento ou estanques, simultâneas aos fatos ou não. Em decorrência de tal fato, surge a necessidade de se investigar mais a fundo a relação do sujeito e tais imagens, com o intuito de verificar a natureza de tal relação e se ela é capaz de propiciar uma experiência com alto grau de comprometimento e envolvimento como a da comunicação. 


\section{Capítulo 2 \\ Caminho sem trilhas}

O fenômeno comunicacional, visto como um Acontecimento, como abordado no capítulo precedente, exige uma postura diversa do pesquisador que a ele se dedicar. Um outro olhar para o objeto é necessário, pois há a necessidade de mantê-lo vivo, com suas energia e vibração intactas. Outras ferramentas devem ser utilizadas, diversas do modelo tradicional de pesquisa. Para tanto, uma outra metodologia deve ser aplicada.

A proposta de um novo método para os estudos dos fenômenos comunicacionais denominada metáporo, desenvolvida no âmbito do projeto "Nova Teoria da Comunicação", apresenta-se como uma nova visão acerca dos procedimentos de pesquisa e do próprio papel do pesquisador nessa, ao deixar evidente o fator subjetivo envolvido. Dessa forma, em vez de se utilizar de um envolvimento velado do sujeito-pesquisador, na busca de uma veracidade pela pseudo-imparcialidade diante do objeto, o metáporo busca, pelo contrário, uma legitimação dos resultados da pesquisa exatamente ao apresentar o pesquisador envolvido pelo fenômeno e divulgando suas impressões, em busca de descrever uma situação, uma cena que possa ser reconhecida por seus pares como uma possível interpretação do objeto.

O nome metáporo é uma alternativa ao método, pois esse (meta + odos) é utilizado normalmente com o sentido de rota instituída, rota traçada. Gilles Deleuze e Félix Guatarri (DELEUZE \& GUATARRI, 1997, v. 5, p.184-190) falam de espaço liso e espaço estriado: o espaço liso, o

2 A referência para a metodologia é o material desenvolvido por Ciro Marcondes Filho durante as discussões do Núcleo de Estudos Filosóficos da Comunicação - Filocom, da ECA/USP, disponível na biblioteca de tal instituição: MARCONDES FILHO, Ciro. Princípio da razão durante, especialmente capítulo 13. 
nomos, é o local do campo pré-urbano, do nômade, onde não há rotas nem caminhos definidos; em contraposição, está o logos, espaço da cidade, com suas rotas predefinidas, suas ruas e calçadas. Em um (liso), situa-se o local do nômade, do colhedor, espaço da territorialização e da desterritorialização; no outro (estriado), encontra-se o local do sedentário, do agricultor, espaço da codificação e da decodificação. Da mesma forma é definido o pensamento, distinto para aquele que busca o inesperado daquele que segue pelas vias seguras.

São nômades por mais que não se movam, não migrem, são nômades por manterem um espaço liso que se recusam a abandonar, e que só abandonam para conquistar e morrer. Viagem no mesmo lugar, esse é o nome de todas as intensidades, mesmo que elas se desenvolvam também em extensão. Pensar é viajar [...]. Em suma, o que distingue as viagens não é a qualidade objetiva dos lugares, nem a quantidade mensurável do movimento - nem algo que estaria unicamente no espírito - mas o modo de espacialização, a maneira de estar no espaço, de ser no espaço. Viajar de modo liso ou estriado, assim como pensar... (DELEUZE \& GUATARRI, 1997, v.5, p.189-190)

As pesquisas que tentam captar o Acontecimento buscam o insondável, o algo novo e inesperado. É claramente um pensamento diverso do utilizado pelo método tradicional; é o pensar de modo liso, evitando as ruas já conhecidas e criando suas próprias rotas. Por isso metáporo (meta + poro), um abrir de novos caminhos, uma busca pelas brechas, pelas frestas, pelos póros. O póro é o que dá passagem por entre a pele, é o que liga o interior e o exterior, é o que, no contato entre corpos, permite o penetrar e a junção.

O pesquisador, por esse instrumento, é um nômade, um explorador de novos horizontes. O nomadismo pressupõe um caminhar errante por terrenos desconhecidos, em que a meta não é um fim, é apenas uma estação intermediária. Portanto, trata-se de um quase-método, pois dá suporte para o caminhar no campo liso, sem definir as rotas previamente.

Os procedimentos do metáporo se dão em três passos ou momentos da pesquisa. $\mathrm{O}$ primeiro passo é o das condições de possibilidade de aplicação do quase-método para o objeto de pesquisa e para sua observação; o segundo trata da própria observação do objeto; e o terceiro versa sobre a apresentação final dos resultados. Nesta pesquisa, como já adiantado, será 
utilizado o metáporo e, para descrever sua metodologia e justificar a escolha pelo quase-método, serão utilizados esses três passos para demonstrar a viabilidade de sua aplicação para o estudo do fenômeno da interação das imagens contemporâneas e a percepção humana na sociedade tecnológica atual.

\section{Condições de possibilidade}

Uma condição necessária para a observabilidade de um fenômeno comunicacional é considerar sua condição de estar sempre em movimento, algo contínuo que não para e nem deve ser cristalizado para ser observado. Aplicando-se tal princípio para o objeto desta dissertação, vê-se que tal fenômeno se encaixa perfeitamente nessa condição, pois trata-se justamente da interação entre as imagens e os sujeitos; como não se trata de um estudo analítico de um determinado tipo de imagem, nem de um determinado meio pelo qual foi produzida, a pesquisa se volta justamente para a atmosfera criada pelo conjunto das imagens tecnicamente produzidas e como essa cena que nos envolve interage com nossa percepção do mundo. Tal atmosfera é alimentada de maneira ininterrupta e por diferentes formas, e sua presença se dá justamente por meio do bombardeio incessante de imagens ao qual estamos sujeitos cotidianamente. É um movimento contínuo e, por ser tão presente e nos circundar de forma tão intensa, muitas vezes pode passar despercebido. O objetivo da pesquisa é captar impressões desse fenômeno, sem a pretensão de analisá-lo cartesianamente, mas sim de poder demonstrar suas presença e atuação em nossa percepção do mundo. A razão de ser do estudo é justamente olhar o movimento como um todo e participar dele, a fim de descrevê-lo em suas fugacidade e intermitência.

Outra condição para a aplicação do procedimento metapórico é a capacidade de se deixar envolver pelo fenômeno que o pesquisador deve ter para poder descrevê-lo. O objeto da pesquisa deve ter como princípio essa característica de atmosfera, de cena, na qual os sujetos se diluem e dela fazem parte. O fenômeno das imagens na contemporaneidade é exatamente um clima entorpecente que circunda a todos e interfere na percepção e na interação com o mundo. Para estudá-lo, é necessário se deixar envolver para poder sentir sua manifestação e seus efeitos, pois só dessa maneira é possível senti-lo e, assim, descrevê-lo com vivacidade e legitimidade. 
O principal instrumento para a observação desse fenômeno é a intuição. A intuição, segundo Henri Bergson, não possui nada de imprecisa, ao contrário, ela é um dos métodos mais elaborados da filosofia (DELEUZE, 1999, p.7). Pela intuição, pode-se vislumbrar o que os seres são em si próprios, o que não ocorre nos métodos analíticos que só permitem chegar ao exterior dos seres. A intuição funde a visão concreta e a penetração pelo qual se pode sentir o que não é aparente.

O metáporo pressupõe uma apreensão do real de maneira instantânea, sensível, como um todo e sem conceitos. Essa apreensão é a intuição sensível, momento em que se vislumbra o todo e se permite conviver dentro do objeto, para senti-lo completamente. Mas pode haver uma intuição intelectual antes, como uma preparação para a apreensão do fenômeno, e depois, para fazer correlações entre esse e o conhecimento geral. No caso desta dissertação, a intuição intelectual norteia todos os preparativos para a defrontação com o fenômeno, é ela que norteia a pesquisa prévia a fim de montar uma arcabouço intelectual para a apreensão; ela também esteve presente quando da definição do objeto, dúvida que fez com que se buscasse a pesquisa acadêmica como meio de compreender algo novo e até então sem definição.

\section{Observação do objeto}

A etapa de observação do objeto é especialmente importante para a aplicabilidade do metáporo na pesquisa, já que aquela define de maneira incontestável o posicionamento do pesquisador. No metáporo, não há espaço para uma falsa imparcialidade, uma objetividade sem aspas; o que há é uma objetividade entre aspas, uma consciência de que o pesquisador participa, e o deve fazer, da própria pesquisa, e que os resultados estão intimamente ligados a sua subjetividade. A objetividade entre aspas torna-se assim mais confiável, pois não esconde a participação do sujeito-pesquisador, pelo contrário, essa é imprescindível para a pesquisa.

Ao pesquisador metapórico, há três posicionamentos possíveis: 1) colocando-se ele mesmo como objeto de observação, para sentir em sua própria mente e em seu corpo os efeitos comunicacionais. Nesse caso, o pesquisador se deixa levar pela intuição sensível e tenta penetrar no objeto para senti-lo em si mesmo, além de sua aparência, e usa seus relatos para expô-lo; 2) situando-se junto ao(s) outro(s) que está(ão) sendo estudado(s), para acompanhar suas reações 
e sua forma de tratamento das impressões. É um posicionamento do tipo etnográfico, que exige do pesquisador uma abertura para sentir as reações do outro, suas mudanças de estados de espírito; e 3) colocando-se a uma certa distância do processo comunicacional, através de vidros isolantes ou mesmo por meio da observação de fenômenos coletivos. Apesar do distanciamento do outro no terceiro caso, é possível ainda capturar uma certa atmosfera de um determinado Acontecimento pelas reações dos envolvidos.

No caso desta dissertação, é imprescindível que o pesquisador se posicione como um ser imerso na atmosfera do fenômeno das imagens, que seja envolvido por ela e esteja aberto para captar o Acontecimento em seu estado mais instantâneo. Para tanto, dentre as três formas de posicionamento do pesquisador propostas pelo metáporo, a que parece ser mais eficiente para o caso em questão é a primeira. O pesquisador deve, portanto, observar-se dentro do fenômeno e atentar para os efeitos que isso gera em sua consciência, ou seja, como o turbilhão de imagens afeta sua percepção do mundo e, por consequência, a construção da realidade. É por meio de suas reações na interação com o fenômeno que é possível aproximar-se dele, são as sensações apresentadas a partir dessa interação que serão a base para a descrição do Acontecimento e, portanto, a base da pesquisa.

Ainda é possível a aplicação do segundo posicionamento apresentado, como um paralelo, uma medida para comparação, a fim de se escapar de divagações que sejam profundamente individuais. Ao se buscar a contra-efetuação, na tentativa de uma descrição capaz de ser reconhecida pelos pares, é interessante estar atento para a participação dos outros no movimento, registrar suas percepções, para que sejam utilizadas como um meio de filtragem, para que a descrição final seja o mais reconhecível possível por quem mais esteja envolvido no fenômeno. Os resultados dessa observação de segunda ordem não necessariamente aparecem na descrição final, mas servem como uma medida para possíveis correções na rota de imersão na atmosfera do fenômeno.

Outra característica marcante do metáporo é o caminhar errante pela pesquisa, o que é adequado no âmbito do estudo das imagens. A capacidade de se deixar guiar pelo próprio fluxo do movimento, sem conceitos pré-concebidos e sem expectativas, é imprescindível para a captação desse fenômeno. O objetivo é pesquisar sem o olhar viciado do pesquisador, sem tentar 
recortar o fenômeno de sua própria atuação e de alguma maneira dissecá-lo, o que acabaria com seu componente vivo e o que há de inédito na pesquisa. É necessário perder-se nessa atmosfera, guiar-se pelo próprio movimento, sem roteiros ou guias, participar do fenômeno no que há de mais intenso e fugidio.

\section{Apresentação dos resultados}

O terceiro momento metapórico é o da apresentação dos resultados. Conforme explicita o metáporo, tal apresentação deve partir da efetuação (relato pessoal) e buscar a contra-efetuação, uma descrição do fenômeno que transcenda a singularidade e alcance o tempo em estado puro. É a tentativa do pesquisador de passar ao leitor aquilo que foi vivenciado por ele, suas sensações e sua experiência ao identificar e apreender o Acontecimento.

Tal posicionamento atende ao objetivo da pesquisa com as imagens. Sendo essencial para o desenvolvimento de tal estudo a participação no fenômeno, na tentativa de captar sua vivacidade e participar de seu movimento, é esperado que tal vivência seja transposta ao relato escrito, de forma a transmitir ao leitor as sensações diante do fenômeno. $\mathrm{O}$ impacto que o turbilhão de imagens tem nos sujeitos contemporâneos não deve ser descrito de forma analítica, como algo a ser dividido e analisado em partes para se entender o todo; deve, pelo contrário, ser descrito como um todo, como algo que nos atravessa e nos transforma indelevelmente, mudando nossas estruturas de pensar e sentir o mundo. O Acontecimento a ser descrito é como um atropelamento, como uma onda do mar que nos pega de surpresa e nos leva ao chão com sua força, não nos deixando pistas de quando começou e de quando terminou; resta ao pesquisador se deixar atropelar pelo movimento e transpô-lo de maneira fiel, com todas as sensações que o envolveram.

A contra-efetuação, nesse caso, buscará a geração do Sentido. Tentará, por meio da descrição do fenômeno, organizar as diversas sensações vivenciados por quem participa do Acontecimento e, a partir das inúmeras dotações de sentido setorizadas, organizar a totalidade em um Sentido.

Sobre a escrita propriamente dita, deve-se buscar, como aponta Gilles Deleuze sobre a obra de Nietzsche, atingir o sentido fora do texto, no extratextual: “Trata-se antes de encontrar, 
de assinalar, de reunir as forças exteriores que dão a tal ou qual frase de Nietzsche seu sentido libertador, seu sentido de exterioridade" (DELEUZE, 1985, p.62). Ou seja, deve-se buscar uma escrita que traga elementos reconhecíveis pelos demais pares da sociedade, em que a compreensão do texto se dê fora dele, no relacionamento entre elementos intra e extratextuais. Além disso, deve ser uma escrita fluida, aberta, que não fixe definitivamente conceitos, que não engesse ideias, mas sim as apresente de forma viva e em constante mudança; deve, portanto, em vez de trazer conclusões definitivas, descrever o fenômeno e apontar correlações somente, sem dá-lo por completo. "Através de todos os códigos do passado, do presente, do futuro, trata-se para ele de fazer passar algo que não se deixa e não se deixará codificar [...] fazer passar algo que não seja codificável, embaralhar todos os códigos” (DELEUZE, 1985, p.57-59).

\section{Aplicabilidade na pesquisa}

A apresentação do metáporo como uma alternativa de procedimento de pesquisa para os estudos de comunicação, como abordado ao longo deste capítulo, teve um grande impacto para o desenvolvimento da pesquisa, pois demonstrou a possibilidade de se abordar o objeto comunicacional em sua vivacidade, como um Acontecimento, e descrevê-lo como tal. O metáporo liberta das amarras ortodóxicas da pesquisa acadêmica e apresenta a possibilidade de vivenciar o objeto da pesquisa por dentro, sem a visão científica desejosa por antever os resultados e dando espaço ao inesperado.

A possibilidade de se fazer parte da pesquisa, ou melhor, a necessidade disso, atende de forma sem igual ao objetivo do estudo, pois o seu início foi a intuição sensível de que algo acontece na interação das imagens e dos sujeitos e, partindo-se desse fato, tem se aplicado a intuição intelectual para preparar o momento de apreensão sensível e posterior descrição do fenômeno. Isso, por si só, já é um bom motivo para a aplicação do metáporo para a pesquisa, pois no método convencional é difícil partir de uma constatação sensível para iniciar a pesquisa.

Como o próprio metáporo demonstra, nada está acabado, nunca há apenas uma conclusão definitiva e não é necessário antever resultados; por essa razão, são feitos aqui alguns apontamentos iniciais sobre a aplicação do procedimento metapórico na pesquisa sobre a interação com as imagens na contemporaneidade. 
O objeto proposto é adequado para a utilização do metáporo, pois atende ao princípio de estar em movimento contínuo e produzir uma atmosfera possível de ser penetrada e de se fazer parte dela. As imagens contemporâneas nos envolvem de forma consistente no cotidiano, criando um clima do qual nem se percebe que se faz parte, mas que interfere de maneira radical em nossa interação com o mundo. O ineditismo da pesquisa é justamente abordar esse fenômeno como um todo, é descrever o impacto que ele faz nos sujeitos e como eles são alterados por essa relação.

A observação do fenômeno das imagens precisa de uma abordagem vivencial, pois a participação do pesquisador no movimento traz a confiabilidade que uma abordagem externa, afastada, nunca poderia alcançar. É necessário se deixar levar pelas imagens, caminhar por esse turbilhão imagético sem conceitos, a fim de captar o fenômeno como um todo em sua forma mais viva. A observação, nesse caso, é essencialmente sensorial, e o próprio pesquisador deve observar a si mesmo na busca de compreender como esse fenômeno o modifica, como ele é alterado no atrito do Acontecimento.

A descrição metapórica é, sem sombra de dúvida, a mais adequada para o objeto, pois permite que a subjetividade se apresente na busca da transcendência da singularidade, ou seja, a partir da vivência individual, busca-se o que há de mais geral, o que pode ser identificado pelos pares como uma descrição verossímel e adequada para o Acontecimento. Na tentativa de repassar o vivenciado, o pesquisador deve evitar assumir discursos alheios e se ater à sua experiência como parte do fenômeno, sem se amarrar a conceitos definitivos, nem conclusões fechadas. $\mathrm{O}$ objetivo primordial é apresentar uma possibilidade de abordagem do fenômeno, sem a pretensão de ser única e definitiva, a fim de ser utilizada por outros pesquisadores como uma descrição possível e legítima para esse fenômeno comunicacional. 


\section{Caminhar por entre imagens 2}

A tela me apresenta todas as possibilidades. Em um primeiro momento, ainda sei bem qual minha posição na situação, o que devo fazer. Com o desembaralhar das inúmeras imagens, um certo encantamento me é apresentado. Sinto-me sendo carregado. Em alguns momentos, resisto, resquícios de uma vontade de controle da situação; em outros, perco a noção de tempo e espaço, submergindo no encantamento.

As imagens parecem ter a intenção de me levar para algum lugar. Não sei bem se é um lugar físico ou um estado de consciência outro, só sinto que sou levado por elas. Outrora eram as sereias, cujo canto encantava os navegantes e os levavam para lugares desconhecidos e perigosos, por vezes fatais. Já as imagens, mesmo não tendo uma intenção consciente ou uma missão destrutiva, parecem fazer parte do mesmo campo místico do encantamento. Elas apresentam outros mundos, outras paisagens, um outro tipo de vivência não mais presencial. É uma existência virtual, realizada apenas no momento em que a imagem invade meus olhos e se reflete em minha retina. No entanto, sinto falta dos outros sentidos, sinto falta do cheiro da paisagem, minha pele se ressente por não poder tocar aqueles objetos e não sentir o calor daquele momento. As imagens, tão nítidas, tentam suprir essas faltas com cada vez mais detalhes, mais riqueza de texturas visuais.

Passo meus olhos pelas imagens e tento fazer uma leitura de sua superfície. Uso o mesmo mecanismo utilizado para decifrar os códigos da escrita. Vago a visão de um canto ao outro, em 
busca de detalhes de uma trama que possa ser desvencilhada. O que pesa contra isso é a rapidez com que as imagens se movem, a cada segundo é uma nova superfície a ser vasculhada. O que fica é a sensação de algo sem fundo, sem um anteparo por trás que a suporte. Talvez por sua natureza digital a imagem perde qualquer materialidade: não se tem um suporte, ela é apenas uma construção de feixes de luz em escala mínima. Como fastasmas, elas estão ali, mas não possuem corpo físico, apenas se apoderam de um aparato tecnológico para fazer sua aparição.

A própria tela, último resquício material, não possui qualquer força sobre as imagens; elas parecem se apoderar dela e puxam o olhar para dentro e para o centro. É como se um grande vendaval te puxasse para seu centro, o olho do furacão. O que está fora do centro perde importância com o tempo. O ambiente externo, o teclado, a tela, tudo converge para as imagens, enquanto vai perdendo força e espaço no campo de visão. O mundo torna-se pálido diante do brilho incessante das imagens.

O espetáculo proporcionado pelas imagens traz uma vivacidade sem igual. O brilho, as cores e o ritmo em que elas vão surgindo seduzem, tornando a jornada por entre elas de certa forma irresistível. Elas me apresentam um mundo mais interessante, mais perfeito, encantador. As lembranças que eu tento evocar da realidade perdem a força no duelo com as imagens: elas são, naquele momento, a visão alentadora de um mundo imperfeito.

Os pequenos períodos entre um vídeo e outro não afetam a sensação de encantamento. $\mathrm{O}$ ato de clicar para iniciar um outro vídeo torna-se mecânico e a seleção dos conteúdos, cada vez mais aleatória. Por sua vez, os atos provocados pelos vídeos, o riso, a tensão e a comoção, perdem força, suavizam-se com o tempo. Sinto-me anestesiado emocionalmente, chegando ao ponto de não me sensibilizar com o enredo das narrativas. É como se a rodada vertiginosa de vídeos calejasse meu ser e o tornasse indiferente ao que é visto. A imagem me transporta para a situação, mas não consegue me tocar. Não me comovo mais com o que me é apresentado. É um processo gradativo, mas sinto a minha sensibilidade se perder.

Mesmo meus outros sentidos vão se enfraquecendo. No início, sinto o desconforto da posição em que estou, em alguns momentos sinto frio, em outros calor. No entanto, sinto meu corpo 
se esvaindo dos sentidos, o passar das horas não pode ser mais medido pelas dores em meu corpo. Mesmo meus ouvidos, alertas para os sons dos vídeos, vão se enfraquecendo, perdendo importância. Já não posso distinguir todas as palavras ditas, todos as camadas de sons; fica apenas um zumbido permeado por signos reconhecíveis. Os sons do ambiente externo perdem qualquer importância.

Passo a ser somente os olhos. Sou todo o sentido da visão. Sou o inverso de uma pessoa com deficiência em algum dos sentidos que passa a ter os demais com um maior grau de apuração: vou enfraquecendo meus sentidos em prol da visão. Percebo que meus olhos, antes em intenso movimento circundando as imagens, pousam suavemente em uma região mais central da tela.

Conforme as imagens vão dando seus saltos, de uma tomada de câmera para outra, de um vídeo a outro, sinto em mim um empurrão, um choque, uma quebra no envolvimento. Com o tempo, essas sensações se enfraquecem e me deixo levar com mais suavidade. Mas mesmo assim, não é algo totalmente tranquilo, como uma navegação em águas estáticas; as quebras das imagens, de forma não ritmada, não permitem uma imersão total. A sensação é de uma eterna imersão e dispersão, em um jogo sem fim que amortece os sentidos e os sentimentos.

O encanto das imagens é da ordem do entorpecimento. Elas fazem com que seus sentidos sejam enfraquecidos e que apenas a visão prevaleça. Mas mesmo a visão se torna refém de tal encanto: ela opera como canal apenas entre as imagens e sua consciência. Em determinado ponto, não tenho mais a sensação consciente do meu olhar, como se meus olhos fossem apenas uma porta de entrada para as imagens.

O poder entorpecente das imagens é refletido em todo o meu corpo. É como se eu tivesse sido anestesiado e entrasse em estado de letargia profunda. Parece ser esse o jogo das imagens: encanto e entorpecimento. Elas me seduzem para que eu embarque nessa jornada guiado por elas, atraem toda a minha atenção para elas, até o ponto em que eu me torno apenas um ser bombardeado pelo turbilhão imagético. Por mais que eu tenha lampejos de consciência, a sensação predominante é de um transe que me deixa inerte e passivo diante delas. 
Minha percepção é toda afetada pelo turbilhão frenético de imagens. Sinto-me envolvido pelo ritmo com que elas vão passando e mudando. Todo meu corpo também pulsa com as mudanças das narrativas. Começo a sentir que estou em sintonia com o que é apresentado. Não é uma relação com o conteúdo, pois já não consigo assimilar de maneira consciente o que assisto; estou ligado ao espetáculo visual apresentado. Sou levado pela vaga que me prende a atenção e não me permite ir em posição contrária.

Conforme as imagens se sobrepõem, a inércia toma meu corpo totalmente. Não só meu corpo; minha mente está envolvida por tal sensação. O pensamento deixa de ser articulado e não mais consigo aliar as imagens vistas com algum conceito do meu repertório. É como se minha mente fosse totalmente esvaziada. Entretanto, é um vazio repleto de imagens que me bombardeiam. Em determinado momento, as imagens tornam-se ocas, assumem apenas a característica de espetáculo para os olhos. Elas não mais me remetem a outros conceitos.

A cada instante, percebo-me caminhando para uma letargia, tanto de corpo quanto de mente. As imagens vão me envolvendo e, como um mantra, esvaziam meus pensamentos. É a sensação de se estar em um sono profundo, permeado por rápidos momentos de lucidez.

Os poucos instantes em que emerjo, sinto uma tontura, um certo grau de desorientação dos sentidos. Tais momentos ocorrem principalmente nas quebras, momentos do clicar para iniciar um novo vídeo. A sensação é de acordar após um sono de meio de tarde, em que se fica meio desorientado e zonzo. Mas ao contrário do sono, não sinto que estou relaxado ou descansado; sinto-me cansado, sobrecarregado, com o corpo pesado, isso sem ao menos ter feito qualquer movimento nesse tempo todo.

A sensação de mal estar faz com que eu retorne rapidamente minha atenção para as imagens. Elas funcionam como uma fuga, pois ao voltar a me conectar a elas, volto a não mais sentir meu corpo e seu possível desconforto. Mesmo o cansaço visual não se faz presente. Talvez também porque pouco se movimentam meus olhos.

Quanto mais mergulho nessa corrente de imagens, mais elas perdem a força expressiva. O conteúdo delas não me afeta. Chega ao ponto de eu nem mais cogitar tentar compreendê-las: elas parecem apenas dançar ao meu redor e minha mente perde o interesse em tentar desvendá-las. 
Nesse ponto, já não sou capaz de descrever com detalhes o que vejo; nem ao menos os assuntos abordados nos vídeos. Minha capacidade de compreensão está comprometida. Diferentemente de um filme, em que ocorre a imersão muito por causa do enredo que te envolve com seus clímax e anticlímax, o mergulho nos vídeos da internet me envolve pela constante mudança: sua diminuída duração faz com que eu não me prenda à narrativa. Com isso, percebo que com o tempo a própria narrativa perde em importância para o ritmo das imagens, sua constante sobreposição. Tais mudanças operam como um mecanismo de hipnose, que me faz esquecer tudo ao meu redor e me faz querer avançar cada vez mais nessa jornada.

Percebo que o procedimento de enfraquecimento dos sentidos, da sensibilidade e da própria consciência faz com que eu perca a própria noção de existência. É como se meu ser fosse eclipsado pelas imagens no momento em que elas se apoderam de minha mente. O entorpecimento é tamanho que perco a sensação de estar ali, diante de uma tela vendo vídeos. Não posso mais me diferenciar das imagens, é uma completa fusão. Meu pensamento autônomo se esvai na enxurrada de imagens que me atravessam.

As imagens oferecem uma realidade radical, pois tomam meus sentidos de assalto e tornam meu corpo obsoleto, inapropriado para essa jornada. Uma totalidade me é ofertada, como uma opção às outras vivências possíveis. As imagens se bastam em e por si sós. É possível viver entre elas. Elas são uma opção ao mundo desgastado e apático, são mais vivas, vibrantes, cheias de possibilidades. Com seu poder entorpecente, conseguem apagar tudo o que está fisicamente ao meu redor e me preenchem, fazem com que me esqueça das intempéries da vida cotidiana. Tudo parece mais fácil e belo, mais simples e espontâneo. 


\section{Parte II}

\section{As imagens e a percepção}

Em estudos que de alguma forma tratam de questões relacionadas ao conceito de imagem, é imprescindível que se delimite de alguma maneira a que tipo de imagem se faz referência. Uma breve reflexão aponta para uma tipologia da imagem na atualidade, a qual compreende as suas mais diversas manifestações: gráficas - aquelas que se manifestam por meio de uma superfície concreta, como o desenho, a pintura e a fotografia; óticas - produzidas a partir da utilização de princípios físicos da ótica, como o espelho e as projeções; mentais - desenvolvidas pelo cérebro humano, como o sonho, a ideia e a fantasia; e verbais - que surgem no jogo da fala ou da escrita, como a metáfora. Tais tipos de imagens elencadas são um simples rol não exaustivo, ao contrário apenas inicial, para demonstrar a complexidade de pesquisas que pretendem versar de algum modo sobre imagens.

No caso desta dissertação, a primeira delimitação necessária é se tratar de imagens visuais perceptíveis. Entende-se por visual uma exterioridade material, ou seja, uma superfície para a manifestação da imagem. Trata-se de imagens exteriores, que estão fora da consciência que se coloca diante delas e possuem existência independentemente do sujeito.

Perceptível, nesse contexto, remete-se ao que sensibiliza os órgãos dos sentidos. Ou seja, a imagem tratada nesse estudo é sentida pelo ser humano como uma manifestação do mundo exterior. Sendo primeiramente visual, trata-se de uma imagem sensibilizadora dos órgãos da visão.

Outra delimitação importante é no que se refere ao meio de produção imagética. No âmbito desta pesquisa, a imagem necessariamente é produzida com a utilização de tecnologia. 
Dessa afirmação, é necessário o esclarecimento do seguinte ponto: no que se refere à produção, não se trata simplesmente do produzir um objeto imagem, mas sim da sua manifestação como tal. Peguemos como exemplo uma pintura. Ela é criação de um ser humano ao movimentar um instrumento (um pincel com tinta, por exemplo) em uma superfície (a tela); até esse momento, é uma imagem tradicional concebida sem a utilização de um aparato tecnológico. No entanto, na reprodução dessa pintura, em sua manifestação em outras superfícies, como impressa em uma página de uma revista, ela passa por um segundo momento de produção, que é o de sua manifestação, intermediado pela tecnologia. Portanto, a imagem contemporânea tratada aqui é tecnicamente produzida, para a qual é necessário o uso de tecnologia para que se manifeste diante do sujeito observador.

A imagem, sob a perspectiva desta dissertação, não necessariamente representa um objeto existente. Portanto, ela não é um signo icônico por si só. Ela, produzida por meio de tecnologia, pode existir sem fazer referência a qualquer real materializado, qualquer objeto concreto. A imagem contemporânea, adotada aqui, pode ser codificada, ou seja, ela pode surgir por meio de um embricamento de códigos que delimitem seu aspecto aparente, sem ao menos ter algo a que se referia. É o caso da fotografia digital, por exemplo. Mais radical, é o caso das imagens totalmente contruídas por código, como as de videogames e de ambientes de realidade virtual: elas não representam um algo exterior, são apenas uma manifestação de códigos. 


\section{Capítulo 1 \\ As vertentes de estudos da imagem na contemporaneidade}

Segundo Vilém Flusser, a humanidade vivenciou duas revoluções na estrutura cultural: a primeira, aproximadamente em meados do $2^{\circ}$ milênio a.C., foi a invenção da escrita linear, inaugurando a História; e a segunda, na atualidade, a invenção das imagens técnicas, produzidas por aparelhos.

As imagens são mediações entre o homem e o mundo; no entanto, elas também têm a capacidade de se entrepor entre eles, deixando de ser mapas do mundo e passando a ser biombos. O homem, nesse caso, passa a viver em função das imagens, em vez de se servir delas em função do mundo. O próprio mundo passa a ser vivenciado como um conjunto de cenas. Nesse caso, o homem passa a viver na idolatria da imagem: incapaz de decifrar os significados da ideia representada, passa a adorá-las. O homem pré-histórico era essencialmente idólatra e contra isso se voltou a consciência histórica, dirigida contra as imagens.

As imagens tradicionais (por exemplo, desenhos rupestres feitos em cavernas pelos homens pré-históricos) abstraem duas das quatro dimensões do espaço-tempo de um fenômeno para conservar apenas as dimensões do plano; a escrita mantém apenas a dimensão da conceituação, capaz de codificar textos e decifrá-los. Dessa forma, o que era uma tentativa de libertar o homem da abstração das imagens acabou se tornando uma abstração ainda maior, afastando-o ainda mais do mundo.

Com a complexidade cada vez maior da linguagem textual, a capacidade de decifrar as imagens às quais a escrita se propõe a mediar para o homem se tornou uma tarefa praticamente 
impossível. A linguagem cada vez mais técnica, em busca da precisão, faz com que os textos sejam inimagináveis, ou seja, não há como transformar os conceitos em imagens novamente, fazendo com que os textos sejam feitos de conceitos vazios.

A História é a explicação progressiva de imagens, desmagicização, conceitualização. Lá, onde os textos já não significam imagens, nada resta a explicar, e a história para. Em tal mundo, as explicações passam a ser supérfluas: um mundo absurdo, o mundo da atualidade. (FLUSSER, 1998, p.31)

As imagens técnicas são produzidas por aparelhos tecnológicos. A técnica utilizada é um texto científico aplicado, fazendo com que as imagens técnicas sejam produtos indiretos de textos. Elas aparentemente não precisam ser decifradas, pois seu significado imprime-se automaticamente sobre suas superfícies, fazendo com que sua relação com o mundo seja apenas de causa e efeito.

O mundo representado parece ser a causa das imagens técnicas, e elas próprias parecem ser o último efeito de uma complexa cadeia causal que parte do mundo. O mundo a ser representado reflete raios que vão sendo fixados sobre superfícies sensíveis, graças a processos ópticos, químicos e mecânicos, assim surgindo a imagem. Aparentemente, pois, imagem e mundo encontram-se no mesmo nível do real: são unidos por uma cadeia ininterrupta de causa e efeito, de maneira que a imagem parece não ser um símbolo e não precisar de deciframento. Quem vê a imagem técnica parece ver o seu significado, embora indiretamente. (FLUSSER, 1998, p.34)

Tal característica faz com que sejam vistas como janelas para o mundo e não imagens, passando uma sensação de confiabilidade. No entanto, são tão simbólicas quanto qualquer imagem, apenas são mais complexas de serem decifradas, pois no caso da imagem tradicional, por exemplo uma pintura, há um agente humano que a produz, colocando-se entre a imagem e seu significado, ou seja, os símbolos são elaborados pelo agente humano, transferidos para o pincel e transpassados para a superfície. Portanto, para a decifração da imagem tradicional, é necessário conhecer o que se passou com o agente no momento da elaboração. Já na imagem técnica, há um agente humano e um aparelho, os quais, aparentemente, não interferem na impressão do 
real na superfície, ou seja, o conjunto agente humano-aparelho aparenta ser apenas um canal transmissor e não um codificador no processo.

O homem atual, segundo Flusser, vive na idolatria das imagens, assim como o homem pré-histórico, entretanto agora é no campo da técnica; ele transfere a magia da imagem (a capacidade de transformar processos em cenas) para o mundo. Vivendo magicamente, ele deseja que tudo se torne imagem técnica, alçada à condição de memória eterna de qualquer empenho humano; como ela é o objetivo de todo ato, passa de ser histórica para tornar-se um ritual de magia.

Apesar de a teoria de Flusser ter sido desenvolvida em referência à fotografia, mais especificamente à analógica, é viável utilizá-lo para a compreensão do fenômeno da profusão de imagens na contemporaneidade, já que o importante é a noção de que as imagens técnicas surgem de textos, de conceitos, ou seja, elas representam prioritariamente a técnica envolvida em sua produção e não o objeto. A técnica é linguagem e é arbitrária: a imagem técnica não apresenta a cor azul, por exemplo, mas sim o conceito de cor azul, o que se convencionou chamar de azul; daí o predomínio do componente simbólico das imagens técnicas, remetendo ao conceito, arbitrário e convencional, e não ao objeto.

Como explicitado por Flusser, o homem contemporâneo não considera o caráter simbólico das imagens técnicas, reverenciando-as como totalmente fiéis ao mundo físico. Essa questão contribui para o fascínio e a posição de destaque que elas possuem na sociedade atual. E tal característica contribui sobremaneira para que o convívio com elas se torne tão fortemente arraigado em nosso cotidiano.

A evolução da imagem analógica para a digital representa, para alguns teóricos, a passagem da representação para a simulação. Edmond Couchot (1993) apresenta uma cronologia de tal situação. Segundo ele, os processos de figuração sempre tenderam a buscar a automatização, em uma tentativa de liberar o olhar e a mão humanos. A partir do século XIX, a busca pelo automatismo ganhou um novo fôlego com a fotografia, a qual inscrevia em um suporte o real sem nenhuma intervenção manual. Com a técnica cinematográfica, surgiu a capacidade de registrar de forma automática o movimento e de reconstituí-lo, e, com a televisão, a possibilidade de fazê-lo instantaneamente. 
Ao decompor a imagem móvel, obtida por projeção ótica sobre o fundo fotossensível de uma câmera eletrônica, em finas linhas paralelas, semelhante ao pantelégrafo, a televisão tornava-se capaz de analisar cada ponto de cada linha da imagem e de reconstituir a imagem sob a forma de uma espécie de mosaico luminoso. Esse mosaico era composto de pontos elementares discretos, vermelhos, verdes e azuis (os luminósforos) que, por síntese aditiva, podiam reconstituir qualquer cor do espectro visível. Mas nem sempre era possível controlar o ponto de imagem com perfeita exatidão, agir por exemplo sobre um único ponto, independentemente dos outros. (COUCHOT, 1993, p.38)

A necessidade, imposta pela própria tecnologia em seu constante aperfeiçoar-se, de controle sobre cada ponto da tela, com a possibilidade de indicá-lo por meio de coordenadas espaciais e cromáticas de forma automática, foi superada com o advento da imagem digital. Ela, graças ao seu caráter de código numeral, substituiu o automatismo analógico pelo calculado.

A procura do constituinte último da imagem concluía-se com o pixel, ponto de convergência, se pode dizer isso, de duas linhas de investigação tecnológica: uma que procurava o máximo de automatismo na geração da imagem; outra, o domínio completo de seu constituinte mínimo. A imagem é, daí por diante, reduzida a um mosaico de pontos perfeitamente ordenado, um quadro de números, uma matriz. Cada pixel é um permutador minúsculo entre imagem e número, que permite passar da imagem ao número e viceversa. (COUCHOT, 1993, p.38)

A revolução provocada pela técnica digital teve como resultado uma mudança na lógica figurativa. A lógica do analógico, ótica, segundo Couchot, pode ser chamada de morfogênese por projeção, pois a construção da imagem se dá por projeção de raios luminosos em uma superfície. Tal lógica pressupõe necessariamente a existência de um objeto real preexistente à imagem, criando uma relação biunívoca entre o real e a sua imagem. A imagem assim representada é uma junção de dois momentos: o de sua captação e o de sua contemplação, alinhando espaço e tempo. "A Representação alinha, no espaço e no tempo, o Objeto, a Imagem e o Sujeito" (COUCHOT, 1993, p.39). A fotografia analógica está sempre ligada ao real através dos fios invisíveis da luz. 
A lógica figurativa iniciada com a tecnologia digital é outra. Enquanto no analógico qualquer ponto da imagem tem um correpondente no objeto real, na imagem digital não há qualquer correspondência entre o pixel e um objeto real. A imagem digital é simplesmente a manifestação visual de um cálculo numérico efetuado por um software. A realidade apresentada pelo digital é uma outra realidade, produzida sinteticamente, totalmente liberada do real. Nesse momento, a representação dá lugar à simulação.

O sujeito não mais afronta o objeto em sua resistência de realidade, penetra-o em sua transparência virtual, como entra no próprio interior da imagem. O espaço muda: virtual, pode assumir todas as dimensões possíveis, até dimensões não inteiras, fractais. Mesmo o tempo flui diferente; ou antes, não flui mais de maneira inelutável; sua origem é permanente "reinicializável": não fornece mais acontecimentos prontos, mas eventualidades. Impõe-se uma outra visão do mundo. Emerge uma nova ordem visual. (COUCHOT, 1993, p.41)

A morfogênese da imagem digital é resultado não mais do concreto, mas do abstrato, de cálculos numéricos, ou seja, de linguagem, como apresentado por Flusser já na questão da fotografia analógica. No entanto, no caso da tecnologia digital, a interferência do conceito é mais radical, pois a própria imagem busca sintetizar toda a complexidade do real segundo leis racionais, buscando criar uma realidade autônoma totalmente virtual.

A exemplo das técnicas figurativas óticas, as técnicas figurativas numéricas são também interpretações do mundo, mas interpretações acentuadamente teorizadas, argumentadas, formalizadas, mesmo quando não o são, em numerosos casos, segundo os princípios da lógica formal e das matemáticas. Elas substituem o real "bruto", originário - o real que a imagem ótica pretende representar - por um real secundário, refinado, purificado no cadinho dos cálculos e das operações de formalização. (COUCHOT, 1993, p.43)

Nessa mesma linha de raciocício vai Jean Baudrillard, que apresenta a questão da imagem como uma forma de simulação, algo que finge existir alguma coisa que não existe. Não há mais diferença entre o real e a simulação; na verdade, a própria simulação ocupa o lugar do real. 
Segundo Baudrillard, a imagem possui quatro sucessivas fases: “[...] ela é o reflexo de uma realidade profunda; ela mascara e deforma uma realidade profunda; ela mascara a ausência de uma realidade profunda; ela não tem relação com qualquer realidade: ela é o seu próprio simulacro puro" (BAUDRILLARD, 1991, p. 13).

A passagem das imagens que dissimulam (fingem não existir) algo para as que dissimulam não haver nada é a virada decisiva do universo da representação para a era dos simulacros e da simulação. Em resposta à perda do real, produz-se mais signos do real: o que traz em si algum sinal de realidade, de algo vivido, é valorizado. Essa produção descontrolada de signos de realidade tem como consequência uma condição em que a consciência humana não mais é capaz de distinguir o real da fantasia e o real é construído cada vez mais saturado, real mais que real: é a hiper-realidade.

A lógica da simulação opera com a não-equivalência: assim como a moeda simula ter um valor que não possui em si mesma, a imagem não mais precisa equivaler a um real por trás dela. Esse modelo é bem condizente com a questão da produção digital de imagens: o real é produzido por uma combinação binária infinita, podendo ser criado e recriado de infinitas formas e intensidades.

O real é produzido a partir de células miniaturizadas, de matrizes e de memórias, de modelos de comando - e pode ser reproduzido um número indefinido de vezes a partir daí. Já não tem de ser racional, pois já não se compara com nenhuma instância, ideal ou negativa. É apenas operacional. Na verdade, já não é real, pois já não está envolto em nenhum imaginário. É um hiper-real, produto de síntese irradiando modelos combinatórios num hiper-espaço sem atmosfera. (BAUDRILLARD, 1991, p. 8)

A sociedade tecnológica contemporânea é o espaço para a simulação por excelência. Nela, as imagens, cada vez mais vívidas, coloridas e ricas em detalhes, aparentam ser mais reais que a própria natureza. As imagens, que a princípio deveriam representar o mundo, acabam por se transformar em um parâmetro para ele. A técnica ocupa o lugar do homem e passa a ser ela a medida de todas as coisas.

A visão de Jean Baudrillard, à parte ter sido muito contestada ao longo dos anos, traz em si um dado interessante, ao relacionar a questão da imagem com uma alteração na percep- 
ção humana. A hiper-realidade, em última instância, é um estado mental em que não mais se distingue o real do ficcional, e as imagens, não mais relacionadas a um referente mas sim a uma trama de códigos que as produzem e as reproduzem à exaustão, ocupam posição central em tal processo.

Uma das consequências da hiper-realidade é fazer com que o mundo físico pareça ser menos interessante que o das imagens. Essas, com a possibilidade de alteração em seus códigos e consequente melhoria em sua qualidade visual, são mais coloridas, vistosas e interessantes que o mundo que representariam. A comparação é vantajosa para as imagens, o que as tornam fascinantes e necessárias como uma fuga da realidade dessaturada.

Outro ponto interessante é o que se refere à quantidade crescente de imagens, dado que empobrece seu significado: quanto mais imagens, menos elas podem ser transformadas em informação. A redundância, nesse caso, trabalha para o empobrecimento da mensagem. Esse aspecto auxilia na formulação de um entendimento sobre o efeito do turbilhão de imagens na percepção do homem contemporâneo.

Uma questão controversa apresentada pela teoria desenvolvida por Jean Baudrillard diz respeito à questão de o simulacro, fruto da simulação, tomar o lugar do real. O simulacro é verdadeiro, pois ele não imita o real; ele é uma gradual substituição dos signos do real, ou seja, simulacro e real possuem o mesmo status. Desse modo, a simulação não se oporia ao real, mas sim à representação: ao substituir o real, a simulação estaria na ponta oposta e geradora da representação. Tal fato levado ao extremo faria com que o próprio real perdesse qualquer importância e, no limite, seria perfeitamente substituído pelo simulacro, ou seja, o simulacro se bastaria por si só.

Segundo Arlindo Machado (1993, p.59), o padrão da imagem digital sempre oscilou entre simular o mundo real ou simular a própria imagem. A simulação do mundo real se dá em construções artificiais cujo objetivo é recriar de forma estilizada fenômenos e comportamentos; no entanto, segundo o autor citado, o mais comum é a simulação da própria imagem, ou seja, o que se busca com a codificação numérica é simular os padrões já conhecidos de representação. No caso da imagem digital, seria a tentiva de se aproximar dos ruídos técnicos em contraponto à perfeição e esterilidade calculada. "O paradoxal é que o padrão fotográfico é reclamado justa- 
mente porque, em razão de seu automatismo técnico, ele é considerado, ao nível do senso comum, o modelo por excelência do 'realismo' visual”' (MACHADO, 1993, p.60).

Segundo Machado, nunca foi objetivo da imagem digital contestar os modelos de representação já existentes; ao contrário, ela busca em tais modelos a sua visibilidade. Para se manifestar como imagem, o código matemático precisa simular regras de visualização e o faz a partir do arcabouço cultural da sociedade humana, por meio de cálculos que simulam as convenções da imagem.

Para visualizar alguma outra coisa que não seja uma lista de números, para obter portanto uma imagem, é preciso forjar elementos específicos de visualização, que não são senão algoritmos de simulação da imagem. São eles - e apenas eles - que tornam possível isso que é a própria função fundante da computação gráfica: a representação plástica de expressões matemáticas. Ademais, é preciso considerar que a imagem é regida por convenções, por regras de formar e até por estereótipos, que são resultado de toda a história da cultura. Portanto, para visualizar expressões matemáticas, é preciso algo mais do que a simples "tradução" dos dados numéricos para a informação de luz projetada numa tela. É preciso, antes de mais nada, posicionar-se em relação a certos ditames da representação plástica acumulados ao longo dos séculos, tal como nos foram legados pela tradição da pintura, da fotografia e do cinema. (MACHADO, 1993, p.60)

Vendo por esse aspecto, a lógica da imagem digital seria a da antiga representação e a simulação entraria somente para forjar uma aproximação com o cânone figurativo tradicional. Dessa maneira, não há a oposição da simulação ante à representação. A imagem digital, por menos conexão com o real que tenha, ainda não conseguiu se livrar das amarras da representação do real.

Sendo simulacros totais ou apenas mais uma forma de representação, o fato é que as imagens tecnicamente produzidas estão por toda parte e nos obrigam a conviver com elas praticamente o tempo todo. Sua presença é tão constante que é possível percebê-las como uma atmosfera densa e fluida, na qual estamos imersos. 
Dietmar Kamper apresenta uma situação parecida com a descrita. Para ele, as imagens possuem a função ancestral de ocupar o lugar do vazio. Elas surgiram como uma resposta à dúvida da morte: como não se sabe explicá-la, nem ao menos se sabe como lidar com ela, cria-se uma imagem para representá-la. As imagens, portanto, trazem em si a imortalidade.

Entretanto, com a profusão de imagens na contemporaneidade, ocorre o seguinte fenômeno: como tudo é representado por imagens, inclusive o próprio homem, diferentes temporalidades convivem simultaneamente; a partir disso, surge uma sensação de indeterminação de se estar vivo ou morto.

Os homens hoje vivem no mundo. Não vivem nem na linguagem. Vivem na verdade nas imagens do mundo, de si próprios e dos outros homens que foram feitos para eles. E vivem mais mal do que bem nessa imanência (permanência) imaginária. Morrem por isso. No ápice da produção de imagens existem maciços distúrbios. Existem distúrbios das imagens que tornam enormemente ambígua a vida das imagens e a morte pelas imagens. Se difunde uma condição do tipo "morto-vivo", "vida morta". Essa impossibilidade de decidir se se está ainda vivo ou morto adere às imagens, pelo menos no momento da sua pura simulação sem referência. (KAMPER, 2002, p.7)

Na atualidade, é cada vez maior a quantidade de "Máquinas de Imagens" e "Máquinas de Olhar" (KAMPER \& BAITELLO JR., 2001, p. 7), capazes de registrar a tudo e a todos como uma forma de coerção. De caráter autoritário, foram pensadas como uma tentativa de pacificar o homem, com o auxílio das distrações decorrentes da tecnologia, para fazer com que se acostumasse com a posição sentada, inerte, e utilizando como calmante as mais diversas formas de entretenimento. Entretanto, de maneira diversa, tal estratégia não só não pacificou o homem, como fez aflorar uma carga ainda maior de violência, só que não dirigida contra um poder político e econômico, ou seja, alia a sensação de impotência à revolta desorientada.

A produção e a distribuição em escala de imagens também colaboram para a perda de sentido na contemporaneidade. Quanto maior a sua quantidade, menor a memória e menor a capacidade das pessoas de recontarem suas próprias biografias, colaborando para a sensação de fragmentação. 
Com as imagens não é possível nem recordar nem esquecer. Sobre esse limite se trabalha continuamente. Em outras palavras, o imaginário é aquele querer esquecer que recorda e aquele querer recordar que esquece. E precisamente quanto menos imagens (a favor de uma única imagem) melhor a lembrança [...]. (KAMPER, 2002, p.11)

Nesse contexto, a humanidade se vê presa em uma verdadeira caverna orbital, composta de imagens circundantes por todos os lados. Nela, é praticamente impossível o surgimento do novo, pois as imagens apenas repetem o já visto e o já vivido, são como espelhos refletindo sempre o mesmo reflexo. As vivências são sempre de segunda mão, não há experiências novas, tudo é sempre uma releitura. As imagens, pois, aprisionam os homens em seu fascínio e em sua transparência turva.

O conceito de caverna orbital desenvolvido por Dietmar Kamper é uma forma de exemplificar a atmosfera que nos rodeia composta pelas imagens contemporâneas. A maior parte do conhecimento que o homem possui do mundo é adquirido por imagens; o homem constrói sua noção de realidade em parte a partir delas. Tal fato já demonstra a importância de se observar o fenômeno das imagens contemporâneas na interação com a percepção do mundo, já que essa se dá de forma diversa na atualidade.

As imagens contemporâneas estão intimamente relacionadas ao meio de distribuição. Não obstante suas diferentes origens, seu destino é sempre tornar-se um emaranhado de dados para ser mais facilmente distribuídas. As imagens contemporâneas são, portanto, mediáticas.

A segunda metade do século XX viu, por um lado, ainda mais a proliferação de obras de arte que não se deixam apreender sem as categorias da comunicação e dos media [...]. E, por outro, viu concomitantemente o crescimento exponencial da produção de imagens mediáticas e seus canais de escoamento. A produção artística parece então se espelhar na imagem mediática ou sobre ela refletir. Este seria um dos sintomas apontando para a escalada das imagens mediáticas e da criação de ambiências nas quais se elas se tornam presença marcante, quando não determinante, e referência axial. Comparada com a produção de imagens artísticas, a quantidade de imagens produzidas pelos media contemporâneos (cinema, jornais, 
televisão, acrescido de potentes novos meios de conservação e distribuição como vídeo, CD, DVD, Internet, www, youtube, blogs e fotoblogs) talvez somente possa ser designada como oceânica: não é possível nem ao menos quantificá-la, nem mesmo por estimativa. Nada mais evidente, portanto, que vivemos em um ambiente iconomaníaco. (BAITELLO JUNIOR, 2007, p.3-4)

As imagens contemporâneas, mediáticas tanto por serem provenientes em sua produção dos media como por serem amplamente distribuídas por eles, estão constantemente dsponíveis para serem acessadas pelo homem. A este resta se resignar e mergulhar no turbilhão de imagens, buscando dessa experiência algum sentido para sua existência. 


\section{Capítulo 2 Tópicos a respeito da percepção}

A imagem contemporânea compreende as mais diversas manifestações: gráficas - aquelas que se manifestam por meio de uma superfície concreta, como o desenho, a pintura e a fotografia; óticas - produzidas a partir da utilização de princípios físicos da ótica, como o espelho e as projeções; mentais - desenvolvidas pelo cérebro humano, como o sonho, a ideia e a fantasia; e verbais - que surgem no jogo da fala ou da escrita, como a metáfora. No caso deste trabalho, delimita-se as imagens visuais perceptíveis, entendendo-se por visual uma exterioridade material, ou seja, uma superfície para a manifestação da imagem. Trata-se de imagens exteriores, que estão fora da consciência que se coloca diante delas e possuem existência independentemente do sujeito. Além disso, são perceptíveis, por terem a capacidade de sensibilizar os órgão dos sentidos, possuindo a característica de se apresentarem como uma manifestção do mundo exterior ao sujeito que as observa.

A percepção humana é tratada por Merleau-Ponty especialmente em sua obra Fenomenologia da percepção. Para ele, a percepção, bem como a própria ciência fenomenológica, está sempre inacabada, é um processo pelo qual buscamos conhecer melhor o mundo, sem nos afastarmos dele, sem o olharmos de fora. No processo fenomenológico, o sujeito está imerso no mundo, faz parte dele e nele está diluído, e disso não se pode e nem se deve escapar durante o ato de exploração para conhecê-lo.

Segundo o teórico, a percepção sempre foi vista, pelas ciências clássicas - empirismo e pragmatismo - como uma relação linear, ou seja, o mundo externo seria captado pelos órgãos 
dos sentidos e posteriormente seria reproduzido pela consciência. Haveria sempre uma relação de ação e reação, uma correspondência pontual e conexão constante entre o estímulo e a percepção elementar. Para Merleau-Ponty, essa relação direta é mais de caráter teórico, pois conflita com os dados da consciência: nem sempre aquilo que vemos ou ouvimos reproduz em nosso sistema as características originais. Uma superfície pintada de amarelo e azul pode se misturar em nossa retina, parecendo-nos esverdeada.

O modelo apresentado pelo teórico parte da fenomenologia, ciência na qual o conhecimento de algo deve ser entendido pelos vários aspectos em que se apresenta. Tudo está interligado e para se conhecer algo, deve-se buscar ao máximo enxergar o todo. Além disso, pressupõe a interrelação entre o eu, o outro e o mundo, não dividindo as coisas para analisar, mas sim vendo-as em conjunto, o qual forma a carne do mundo.

Eu, que contemplo o azul do céu, não sou diante dele um sujeito acósmico, não o possuo em pensamento, não desdobro diante dele uma ideia de azul que me daria seu segredo, abandono-me a ele, enveredo-me nesse mistério, ele "se pensa em mim", sou o próprio céu que se reune, recolhe-se e põe-se a existir para si, minha consciência é obstruída por esse azul ilimitado. (MERLEAU-PONTY, 2006, p.289)

No processo da percepção, para Merleau-Ponty, o corpo exerce um papel fundamental. A percepção se dá pelo corpo. Os órgãos dos sentidos são apenas instrumentos da excitação corporal e não da própria percepção. O corpo é o resultado da inserção do ser no mundo e com ele percebemos o mundo: ele é um espaço expressivo que projeta suas significações no mundo exterior, atribuindo-lhes um lugar e as fazendo existir como coisas, ao mesmo tempo em que o mundo exterior se projeta no corpo, atribuindo-lhe um sentido e uma existência - é dessa dialética fenomenológica que resulta o corpo. Além disso, não é possível separar o corpo e a subjetividade: a percepção se dá com o corpo e o espírito (subjetividade) simultaneamente, tornando a experiência perceptiva sinestésica por natureza.

A percepção sinestésica é a regra, e, se não percebemos isso, é porque o saber científico desloca a experiência e porque desaprendemos a ver, a ouvir e, em geral, a sentir, para deduzir de nossa or- 
ganização corporal e do mundo tal como o concebe o físico aquilo que devemos ver, ouvir e sentir. (MERLEAU-PONTY, 2006, p.308)

As quales (formas, cores) não são apenas aparência, são maneiras particulares de existência. Ao nos depararmos com uma cor, por exemplo, ela não é apenas uma característica da superfície do objeto ou da imagem; ela é uma maneira de vibrar e de preencher o espaço e a percepção, e para se realizar, exige que o corpo todo se entregue a essa maneira de existência e passe a vibrar na mesma frequência dela.

Com a utilização do conceito de comunicação como Acontecimento e a percepção fenomenológica, busca-se uma compreensão do fenômeno da interação do sujeito com as imagens contemporâneas. O Acontecimento comunicacional abre espaço para o novo, o não dado, ele é a própria relação, o processo e é imprevisível. Assim como o fenômeno da percepção, ele não está acabado e não é igual para todos em determinado momento.

A sociedade tecnológica é marcada pela produção incessante de imagens, às quais temos acesso a todo momento pelos mais diversos meios. A quantidade é tamanha que, na maior parte das vezes, não se é capaz de percebê-las devidamente: pode-se ver, mas não perceber. O estímulo visual é tamanho que acaba tornando o sentido da visão predominante:

[...] pesquisas empíricas revelam que, provavelmente devido a razões de especialização evolutiva, $75 \%$ da percepção humana, no estágio atual da evolução, é visual, isto é, a orientação do ser humano no espaço, grandemente responsável por seu poder de defesa e sobrevivência no ambiente em que vive, depende majoritariamente da visão. Os outros $20 \%$ são relativos à percepção sonora e os $5 \%$ restantes a todo os outros sentidos, ou seja tato, olfato e paladar. (SANTAELLA, 1993, p.11)

O predomínio da visão em detrimento dos outros sentidos se acentua com a virada imagética empreendida ao longo do século XX. Nesse contexto, será que há ainda espaço para o novo? É possível o Acontecimento comunicacional a partir das imagens que nos rodeiam?

A percepção fenomenológica é um processo complexo, que exige entrega do sujeito e abertura para se deixar transpassar pelo mundo. Assim como no âmbito da comunicação nem todo diálogo trivial propiciará o fenômeno comunicacional, também nem toda imagem será 
capaz de tocar ao ponto de levar o sujeito a se entregar a ela. Tanto em um quanto em outro caso, a intencionalidade do sujeito é que iniciará o processo: a consciência se volta para algo que a atrai, que a faz querer partilhar dela como experiência.

O importante, em ambos os casos, é a abertura do sujeito ao inesperado, ao outro que está ligado a ele, mas que assim não parece estar. É necessário se abrir para o outro, esvaziar o ego e se deixar preencher pela outra existência.

No caso das imagens, a massificação opera no caminho inverso: os estímulos são tantos que a consciência se torna insensível aos apelos do outro, não há mais espaço para a sensibilização pelo estranho, pelo novo. É necessário uma ressensibilização dos sujeitos, uma abertura maior para o outro, para a fruição imagética, ou se permanecerá indelevelmente na superfície das imagens, sem se deixar tocar por toda a gama de sensações que elas podem proporcionar. A percepção imagética pode ser uma alternativa para se buscar uma nova relação e uma nova vivência em meio ao turbilhão de imagens da contemporaneidade. 


\section{Caminhar por entre imagens 3}

A realidade das imagens me escapa de tempos em tempos, ao final de cada vídeo. Isso funciona como um lembrete de que aquilo tudo é provisório, não é uma opção a ser feita de forma definitiva. É radical, mas não duradoura.

O jogo das imagens se faz por imersão e dispersão. Elas me introduzem a uma vivência perfeita, luminosa, na qual mergulho com cada vez mais interesse e prazer. De outra feita, tiram-me isso com frieza e rapidez, ao fim de cada vídeo. Entretanto, a experiência é tão satisfatória, tão agradável, que me vejo forçado a tentar mais uma vez.

É um jogo desigual, pois estamos em diferentes níveis de força. As imagens me controlam, já que com elas está a chave para iniciar e terminar cada partida. Eu penso ter total independência de decisão, de armar minhas jogadas, mas não passo de um refém de quem possui o mando do jogo. Meu único poder é o de optar entre continuar ou terminar o jogo, ao clicar em outro vídeo ou mesmo parar a exibição.

Já o poder das imagens é mais consistente e forte, porque está com elas a fonte do prazer e elas ditam sua duração. O término de um vídeo é uma amostra da superioridade delas nessa situação, de como elas têm o controle. Sinto-me como um adicto que abre mão de algo seu para atingir a satisfação de seu vício: a falsa sensação de se alienar da realidade ao mergulhar no turbilhão das imagens é um bálsamo em meio ao nem sempre hospitaleiro cotidiano. As imagens oferecem uma fuga, uma válvula de escape, mas não sem pedir algo em troca. 
O fácil prazer oferecido me traz a impressão de tranquilidade, como um bom momento de relaxamento. Com meu corpo e mente anestesiados, tenho a falsa sensação de que tenho um momento de descanso e de introspecção, capaz de me trazer de volta as energias gastas com as demais atividades. No entanto, um momento de relaxamento, atingido pela via que for, pressupõe que se volte às atividades normais com o ânimo recuperado e maior disposição para enfrentar os desafios que surgirem. Não é bem o caso, após o término da jornada por entre as imagens.

Após o período que me dispus para empreender a jornada, encerro a sessão de vídeos. Logo ao me desconectar, volto a sentir a tontura já percebida em outros momentos, durante as quebras sequenciais. Como não pretendo continuar com a sessão, persisto na intenção de retomar minhas outras atividades.

Sinto uma desorientação total, uma incapacidade de formular qualquer pensamento mais complexo. Minha mente está repleta das imagens para as quais me expus, mas não tenho o que fazer com elas, pois elas não me dizem nada. É como se eu tivesse acesso a uma grande biblioteca em que todos os livros são de idiomas totalmente irreconhecíveis por mim: eles estão lá, sei que posso ter acesso a inúmeras informações por meio deles, mas não tenho instrumentos para decifrá-los.

O intenso ritmo das imagens parece se reproduzir em meu pensamento. Sou incapaz de me manter concentrado em apenas um assunto; fico pulando de uma pensamento a outro sem conexão. Minha própria linguagem ainda está no ritmo das quebras: tento explicar a mim mesmo como foram as sensações vividas durante a jornada, mas minhas frases são curtas e muitas vezes sem ligação uma com as outras.

Com a intenção de fazer anotações para a descrição do fenômeno, pouco consigo escrever. Minha expressividade está muito reduzida. Rabisco algumas palavras, alguns conceitos, mas nada muito elaborado. Faltam-me ideias, associações entre conceitos para elaborar um discurso. Falta-me concentração.

Sobretudo, falta-me foco. Tento concentrar minha intencionalidade em encadear pensamentos para formular um texto, o mais simples que fosse, apenas para registrar minhas impressões. Travo 
uma luta intensa com minha mente, pois ela vaga de assunto a assunto, de pensamento a pensamento, vagando ainda ao ritmo das imagens. É difícil me concentrar e ir atrás de um objetivo.

Sinto como se minha mente estivesse ainda tomada pelas imagens. Ao começar uma linha de pensamento, logo essa é atropelada por outra, formando uma roda de ideias a girar com força e rapidez. Fico desorientado, perdido entre tantos assuntos que vagam em mim. Além disso, continuo apático, sem energia para realizar qualquer atividade. É como se a inércia ainda me dominasse e me impedisse de fazer qualquer empreendimento, por mais banal que seja. Meu corpo pesa e minha cabeça, ainda mais.

Decido então mudar meu foco e apenas espairecer. Uma caminhada na rua, ver novos lugares, em busca de um rearranjo de minha ideias. Nesse momento, tenho uma constatação significativa: o mundo real realmente torna-se pálido em comparação com as imagens. É muito nítida essa situação logo após ter me submetido a um longo período de exposição. As ruas parecem mais sujas, as cores todas desbotadas; onde foram parar todas aquelas cores, aquele ritmo frenético?

As pessoas me parecem estranhas, até mesmo assustadoras. Não conseguiria pedir uma informação, caso fosse necessário. Acredito que conseguiria, mas não sem um grande esforço. Nesse momento, sinto como se tivesse perdido a capacidade de interação com as pessoas, o traquejo da sociabilidade. $\mathrm{Na}$ verdade, sinto um pouco de aversão às pessoas: elas esbarram sem pedir desculpas, estão com semblante fechado. Pareço não ter a menor vontade e habilidade de ter contato com elas.

Tenho uma sensação de incomunicabilidade. Não me sinto de nenhuma forma ligado às outras pessoas, nem ao menos propenso a construir qualquer ligação. É como se eu não me identificasse com elas, não me interessasse em ter acesso a seus mistérios. É como se eu mesmo me bastasse; na verdade, eu e meus pensamentos confusos a rodopiar em minha mente.

Demoro a me acostumar com o ambiente externo. Mais do que nunca, sinto-me desprotegido. Vago pelas ruas com receio, medo até, como se todos os atos de violência estivessem materializados naquelas pessoas, naquelas exatas pessoas que encontro nesse caminhar pelo bairro. Qualquer ruído, qualquer toque, tudo me dá uma sensação de insegurança. 
Tento não reparar muito nas pessoas e vago meu olhar para os objetos. Primeiramente, miro as vitrines das lojas: nada ali me traz algum interesse. Ao virar uma esquina, proponho-me um teste: tentar me lembrar de algum detalhe específico de alguma das mercadorias que avistei na rua anterior. Nada feito. Sou incapaz de me lembrar mesmo de um objeto específico, muito menos de um detalhe daquele. Lembro-me vagamente das lojas e dos produtos, mas não posso afirmar com segurança de que o que me lembro é realmente dessa última passagem ou se são memórias mais antigas de outros passeios por essas mesmas ruas.

Decido então me focar em paisagens naturais e parto para um parque. Demoro a ter minha atenção voltada para algo que eu tenha achado belo. Vejo as árvores, as flores e o pequeno curso d'água; são apenas isso, nada neles me chama atenção, nada me deslumbra. As paisagens são muito desinteressantes. Além disso, ao caminhar no parque, estou exposto à dureza da realidade: nem tudo é perfeito. Embaixo de uma grande árvore, há sempre um caminho de pedras escorregadias pela umidade. Sobre o assento de um banco, há sempre escrementos de pássaros. O mundo não é perfeito.

Quando percebo minhas reclamações sobre o ambiente, faço a associação de que só reclamo porque, de alguma forma, eu vislumbro uma alternativa àquilo. Essa é a questão: a vivência com as imagens me trouxe a sensação de uma realidade melhorada, sem os odores nem sempre agradáveis, sem os riscos de qualquer espécie e sem a necessidade de interagir com as pessoas.

Mesmo ao assistir vídeos sobre violência, não me sinto de qualquer forma ameaçado. Ao menos, não durante o momento em que eu o assisto. Eu posso me sensibilizar de alguma forma, posso sentir até medo, mas não se compara à sensação oferecida pelo ambiente externo.

Nos vídeos, posso ver cenas reais, feitas por câmeras em diversos ângulos e com diferentes propósitos. Posso ver imagens belas, muitas delas até com enquadramento estético e por vezes tratamento posterior em sua qualidade; posso ver imagens terríveis, violentas, mostrando fatos injustos e sofrimentos os mais diversos. Os vídeos podem apresentar tudo, formam uma realidade radical, definitiva, completa e irrefutável. No entanto, por mais que saiba do fato e tenha outras evidências da situação que foi filmada, sempre permanece a dúvida. É a dúvida da ima- 
gem: será que o representado por ela é fiel à situação filmada? Ou em outros termos: aquilo que vejo nas imagens realmente aconteceu?

Não é possível ter total certeza de que as imagens apresentadas realmente são referentes a uma realidade qualquer. Ainda mais em se tratando de imagens digitais, que podem ser facilmente alteradas. Como saber se o que é visto em um vídeo é um fato real ou uma construção qualquer?

Eis a fraqueza das imagens: por mais que elas tentem, sempre pairará uma dúvida sobre elas. E se não for verdadeira? Talvez por isso, não consigam me mobilizar como um fato presencial. Além disso, há a questão da quantidade. Agora percebo que a enorme variedade e quantidade de imagens disponíveis afetam minha total identificação com seus conteúdos. Não é como um longa metragem que, grosso modo, faz com que eu me sinta tocado e, de alguma forma, representado por seus personagens e situações. Os vídeos curtos fazem com que eu pule de um ambiente de imersão, proposto por um, para outro ambiente de imersão, tornando a tarefa de me entregar a cada um praticamente impossível. O que permanece é a sensação de nulidade, de falta de qualquer identificação. Torna-se uma jornada para o caos.

Entretanto, algo acontece na relação. Sou modificado após essa jornada. Toda minha estrutura de pensamento e sentidos foi alterada. Posso medir as mudanças ocorridas por meio das marcas deixadas em mim.

Não sei ainda se posso chamar esse fenômeno de comunicação, mas certamente houve um Acontecimento. O que ocorreu me violentou, forçou uma transformação em mim. Sou outro após o caminhar. 


\section{Parte III}

\section{Encanto e entorpecimento}

Com a conclusão da experiência de interação com as imagens contemporâneas, é chegado o momento de tecer alguns comentários que ajudem a compreender a dimensão do ocorrido, mas também que sirvam para propor a discussão a respeito do tema. Por se tratar de uma pesquisa que não busca uma resposta definitiva e única, foram elaborados alguns apontamentos relacionando o já existente em teorias da área com as impressões sentidas após o experimento.

O relato "Caminhar por entre imagens 1, 2 e 3" trouxe as sensações provenientes do fenômeno; agora, busca-se trazer essas sensações para um campo teórico, na tentativa de tornálas mais facilmente reconhecíveis e compreendidas. As partes I e II trouxeram as bases teóricas em que repousa o trabalho e servirão como contraponto e medida de comparação às propostas a serem apresentadas.

Dessa forma, é empreendida a tentativa de partir do individual para o geral, ou seja, de uma experiência do sujeito, buscar relacioná-la ao conhecimento já existente e tentar contribuir para o desenvolvimento de um conhecimento que seja objetivo, mas com componentes de participação subjetiva. 


\section{Capítulo 1 \\ Da impossibilidade de comunicação}

Conforme apresentado no capítulo 1 da parte I desta dissertação, o fenômeno comunicacional está intimamente relacionado ao Acontecimento. Ele é algo que nos afeta a tal ponto que nos transforma, muda nossas estruturas. A partir dele, somos tocados e abrimos espaço para o novo, aquilo que não existia antes e surge desse contato. Esse fenômeno transformador é a comunicação.

A questão colocada a partir da experiência de exposição prolongada aos vídeos aleatórios disponíveis na internet, relatada no texto "Caminhar por entre imagens", é a seguinte: há, nessa interação entre o indivíduo e as imagens contemporâneas, uma relação tal que possa ser identificada como comunicação?

O Acontecimento está presente nessa relação. Durante o processo, senti uma confusão mental, uma perda temporária da consciência da situação em si e de mim mesmo. É como se, naquelas horas em que estive em contato com as imagens, todo o resto perdesse o sentido, tudo parecia passível de ser questionado. A onda de sensações era tão intensa que conseguia enfraquecer minhas estruturas de sentidos, ao ponto de chegar a me questionar, sobretudo ao fim do processo, sobre fatos corriqueiros e a passar a temê-los. ${ }^{1}$

Vejamos a seguinte passagem de Gilles Deleuze sobre a capacidade do Acontecimento interferir na estrutura de sentidos do sujeito:

1 Em "Caminhar por entre imagens 3", descrevo minha perplexidade ao tentar me relacionar, após horas de imersão em um ambiente puramente imagético, com o ambiente externo e como aquilo tudo me parecia assustador. Ou seja, conceitos caros para mim, como a sociabilidade, perderam, mesmo que por alguns instantes, sua força e importância, como se não mais tivessem o mesmo sentido de antes. 
Todas estas inversões, tais como aparecem na identidade infinita têm uma mesma consequência: a contestação da identidade pessoal de Alice, a perda do nome próprio. A perda do nome próprio é a aventura que se repete através de todas as aventuras de Alice. Pois o nome próprio ou singular é garantido pela permanência de um saber. Este saber é encarnado em nomes gerais que designam paradas e repousos, substantivos e adjetivos, com os quais o próprio conserva uma relação constante. Assim, o eu pessoal tem necessidade de Deus e do mundo em geral. Mas quando os substantivos e adjetivos começam a fundir, quando os nomes de parada e repouso são arrastados pelos verbos de puro devir e deslizam na linguagem dos acontecimentos, toda identidade se perde para o eu, o mundo e Deus. [...] Como se os acontecimentos desfrutassem de uma irrealidade que se comunica ao saber e às pessoas através da linguagem. Pois a incerteza pessoal não é uma dúvida exterior ao que se passa, mas uma estrutura objetiva do próprio acontecimento, na medida em que sempre vai nos dois sentidos ao mesmo tempo e que esquarteja o sujeito segundo esta dupla direção. O paradoxo é, em primeiro lugar, o que destrói o bom senso como sentido único, mas, em seguida, o que destrói o senso comum como designação de identidades fixas. (DELEUZE, 2007, p.3)

Como explicado por Deleuze, o Acontecimento tem a capacidade de trazer à tona dúvidas sobre situações antes encaradas como inquestionáveis. A força com que ele se apresenta destrói o que há de fixo e nos força a perceber que não há nada que esteja pronto, acabado; tudo é passível de ser questionado, de ser transformado. O paradoxo, no caso da personagem Alice, e as imagens, no caso desta dissertação, têm em comum a característica de destruir o senso comum, e dessa forma, as certezas, e implantar as dúvidas.

Durante o processo, quanto mais eu me abria para ser bombardeado pelas imagens, menos consciência eu tinha do que acontecia. Eu perdia a cada instante a capacidade de reflexão sobre o que ocorria. Além disso, a força com que eu era tragado pelas sequências de imagens fazia com que eu perdesse a percepção de todo o resto ao meu redor. Eu não tinha mais a clara certeza de que eu estava sentado em frente a uma tela de computador assistindo aos vídeos. A 
sensação era de perda da capacidade de me definir como identidade, como ser cuja intencionalidade guiava o processo. As ações se tornavam tão mecânicas que não mais havia um pensamento racional guiando a experiência.

Mesmo após o término da sessão dos vídeos, tal confusão mental permaneceu por um período. Foi difícil retornar às tarefas cotidianas, como se um novo olhar tivesse se instalado em mim e feito com que tudo ao meu redor não fosse mais tão certo e seguro. Algumas das minhas convicções mais sólidas, como o apreço ao convívio com outras pessoas, o viver em sociedade e o prazer em estar no espaço público foram abaladas. Eu passei a ter um comportamento mais arredio com as pessoas desconhecidas encontradas pelas ruas. O prazer do caminhar sem destino, na expectativa de que algo interessante pudesse ser encontrado, foi substituído por uma sensação de intenso desconforto e desconfiança generalizada.

De uma certa forma, o Acontecimento proporcionado pelas imagens contemporâneas tornou-me mais duro. $\mathrm{O}$ acúmulo dos vídeos fez com que eu perdesse a capacidade de me deixar comover por eles. Por mais que pudessem tratar de temas comoventes ou impactantes, como violência ou retrato de alguma dor humana, ou temas hilariantes e mais leves, a falta de sensação provocada em mim era semelhante. Tornei-me apático, incapaz de me ligar a alguma situação por eles apresentada.

Nessa mesma direção, a experiência tornou-me mais fechado, desinteressado em outras pessoas e novas experiências. Em outras palavras, senti um fechamento interior, como se eu me fechasse em relação a qualquer possibilidade de encontrar o novo. Não havia mais aquela intenção de estar aberto, de me apresentar para novamente ser transpassado pela força do novo.

O Acontecimento foi presente o suficiente para mudar minha disposição em encarar os fatos. De uma atitude aberta, na expectativa de ser surpreendido pelo novo, passei a ter uma posição de retração e intimidação por qualquer situação inesperada. Pelas marcas deixadas, é possível rastrear o Acontecimento em mim. No entanto, ele pode ser considerado comunicacional? Ou seja, a essa mudança ocorrida em meu ser podemos chamar de comunicação?

Segundo Ciro Marcondes Filho, as experiências triviais, como uma conversa descompromissada, a leitura de notícias sobre o cotidiano e até mesmo assistir a um filme sem grandes pretensões, são necessárias para reforçar nossas posições, nossas ideias sobre o estado de coi- 
sas em que vivemos. No entanto, "ao mesmo tempo, sentimos necessidade de coisas novas. Emoções novas, experiências novas, fatos que interfiram em nosso cotidiano criativamente para arejá-lo, renová-lo, refrescá-lo, ventilá-lo. Essa ambiguidade justifica nossa necessidade da comunicação" (2009, p.64). A comunicação estaria relacionada a algo que nos obriga a pensar, ela é em si uma violência, mas uma violência criativa, que nos dá ânimo para seguirmos em frente e buscarmos o não dado.

No caso do Acontecimento proporcionado pelas imagens contemporâneas, não foi bem isso que foi sentido por mim. Em vez de me provocar a pensar, ele subtraiu minha capacidade de refletir sobre a experiência; em vez de me trazer um impulso criativo, ele me proporcionou uma letargia mental.

Se o Acontecimento comunicacional possui um caráter positivo, em forçar o movimento de ideias para o surgimento do novo, o Acontecimento proporcionado pelas imagens é de outra natureza, pois opera no inverso dessa corrente. Ele trouxe o fechamento, a não ligação - com as pessoas e com outros objetos culturais - e a estagnação. Em vez de um sentimento de mudança, trouxe inércia.

Os fatos apresentados levam a crer na impossibilidade de comunicação com as imagens contemporâneas. As condições para haver a comunicação estavam presentes: eu me coloquei aberto para recebê-las; deixei que fosse preenchido por elas; eu me deixei misturar com elas; e voltei minha intencionalidade na expectativa de ser atingido por elas e de permitir que todas as sensações da experiência se manifestassem em mim.

O processo comunicacional entre o sujeito e um objeto cultural se dá quando esse consegue tocar o sujeito a ponto de mudá-lo, acrescentar a ele uma experiência que aumente sua complexidade. Analisando a experiência com as imagens, é possível verificar dois pressupostos que parecem ser de vital importância para a efetivação do Acontecimento comunicacional:

Comoção: é necessário que o objeto comunicacional consiga comover o sujeito. Comover vem do latim commovére - pôr em movimento - e, no caso, é empregado com esse sentido de forçar algo que está estático a entrar em movimento. O novo surge do atrito de ideias e conceitos em movimento, por isso o objeto cultural deve ter a capacidade de instigar ao ponto de colocar em movimento, de nos fazer pensar. A comoção surge 
quando o objeto nos desafia a pensar, tocando no fundo do ser e forçando que repensemos os velhos conceitos. Essa força é a origem da criatividade, é o que faz com que não nos contentemos com o já pronto e busquemos a transformação, a mudança. O objeto cultural deve ser capaz de causar esse impulso mental, deve nos dar um empurrão, que subverta nossos conceitos e os recoloque em outras posições, com a possibilidade de novas conexões, criando um campo propício para o surgimento do novo.

- Empatia: é necessário que haja uma relação de empatia entre o sujeito e o objeto cultural. Empatia vem do grego empátheia - paixão - representa a capacidade do sujeito de compreender emocionalmente o objeto. A ligação entre os dois elementos ultrapassa os limites cognitivos e gera uma identificação mútua, o que leva em alguns momentos a uma integração que chega à dissolução de um no outro, como se ambos estivessem tão próximos que se misturassem e não houvesse mais limites onde um termina e começa o outro. É compreensão que abrange os sentimentos e representa uma fusão.

Tomando por base minha experiência metapórica, vejo que entre os pressupostos apresentados ambos não estiveram completamente presentes. Não houve a comoção, pois a exposição às imagens não me estimulou a pensar e a fazer novas conexões. Pelo contrário, senti uma forte sensação de estagnação, torpor e inércia mental. As imagens não me desafiaram a fazer novas conexões de pensamentos, não me instigaram. Elas simplesmente me levaram à imersão completa, com a perda da noção do espaço ao meu redor e do tempo gasto. No entanto, não houve nenhum impulso criativo, nem durante o processo, nem após o seu término. Aliás, após o fim da experiência, tive dificuldades para recuperar o nível de atenção e concentração apresentados anteriormente.

Quanto à empatia, a análise é mais complicada. Embora tenha havido uma ligação muito forte, chegando a alguns momentos haver uma fusão entre minha consciência e as imagens, não houve um acionamento emocional da minha parte. Não houve uma identificação pessoal, houve mais uma dissolução da minha consciência no caldo de imagens.

A empatia traz um componente emocional, uma compreensão muito além da cognição. Para que ela se realizasse, seria necessário que as imagens fossem capaz de buscar na memória algo que auxiliasse em minha identificação com elas. E, com isso, que se criasse uma relação 
emocional, um elo entre os dois elementos do processo. Porém, as imagens não proporcionaram esse tipo de relação comigo.

Tomando por base os pressupostos de comoção e empatia, pode-se concluir que o Acontecimento não foi comunicacional. Tratou-se de um Acontecimento, mas não trouxe a característica de impulsão do pensar. Ele está mais para a ordem do confundir que do fazer emergir a solução criativa; do obscurecer que do iluminar.

A partir dessa constatação, é possível a formulação de duas hipóteses, discutidas na sequência:

- As imagens em movimento não são passíveis de comunicação. Nesse caso, teríamos de aceitar que o processo cinematográfico não é um potencial incitador do Acontecimento comunicacional. Tal formulação não parece ser um caminho razoável, pois é inegável a força que um filme possui para proporcionar a comoção e a empatia com a plateia. Não raro você é tocado por um determinado filme e aquilo permanece com você muito após o término da sessão, como um pensamento insistente que resiste em dar espaço para outros.

- As imagens digitais não são passíveis de comunicação. A imagem digital prescinde do objeto, pois em sua construção matemática por pixels, a realidade é liberada do papel de modelo e é substituída pela formulação de matrizes. No entanto, mesmo com essa natureza diversa, a imagem digital, ao se utilizar da imagem analógica como modelo, também se utiliza dos componentes narrativos, pode simular os enquadramentos, ou seja, a linguagem cnematográfica ainda está lá. Como no cinema, o vídeo curto pode apresentar os elementos necessários para criar empatia e comoção no sujeito, perturbando-o e levando-o a pensar sobre aquilo muito além do momento do assistir. A tecnologia digital, ao simular o real, ainda o faz de forma a cativar o espectador e quando atende aos princípios convencionais cinematográficos, é capaz de levar ao Acontecimento comunicacional. ${ }^{2}$

2 Por ora, as questões das imagens digitais não parecem ultrapassar os limites do convencional, apesar de terem provocado uma transformação no olhar no produtor da imagem, tanto fotógrafo quanto cineasta: "No que, então, as técnicas de figuração numérica modificam alguma coisa na arte? Elas o fazem na medida em que são empregadas para controlar todas as imagens automáticas (fotografia, cinema, televisão) pois estas serão, a curto ou 
Nos casos dos vídeos disponíveis na internet, as fontes são ilimitadas. Pode-se tratar de um trecho de um filme convencional analógico, ou um filme doméstico amador digital, ou mesmo um vídeo-arte feito especialmente para a visualização online. Portanto, são vídeos advindos de um sem número de processos que culminaram no digital, ou por conversão do analógico para o digital ou por já serem produzidos digitalmente. A questão da impossibilidade de provocar a comunicação não parece relacionada à natureza do vídeo, mas sim à sua apresentação.

A internet tem se mostrado cada vez mais uma plataforma de junção de diferentes meios. Em vez de se constituir como um novo meio de comunicação, ela se apresenta majoritariamente como um canal de distribuição de conteúdos advindos de outros meios, ou mesmo que poderiam estar disponíveis em outras plataformas. Não obstante os esforços de se produzir vídeos diretamente para a internet, a maior parte desses ainda são produzidos sob os cânones de quando eram pensados para os outros meios.

A grande diferença da internet é a capacidade de disponibilizar conteúdos variados nunca antes alcançada por nenhum outro meio. A quantidade de dados disponíveis é infinita e o acesso é praticamente ilimitado. No caso dos vídeos, o possibilidade de conteúdos e diferentes processos de produção empregados para sua confecção é assustadoramente grande, com alimentação descentralizada e contínua a todo momento.

Com tamanha diversidade e quantidade, a possibilidade de se chegar à comunicação deveria ser maior, já que as opções são variadas e se um vídeo não for capaz de criar laços de empatia e comoção com o espectador, depois daquele há alguns milhares de outros à disposição para cumprir essa tarefa. Então por que não é possível atingir a comunicação com tamanha quantidade de vídeos?

A resposta parece estar presente na própria questão: a enorme quantidade de vídeos. No caso do fenômeno da comunicação, a quantidade interfere na possibilidade de sucesso do processo. Para haver a comunicação com objetos culturais, é imprescindível que, além de o sujeito estar aberto para ser atingido pela experiência, não impondo barreiras para que ela se manifeste inteiramente em seu ser, o objeto também represente um desafio, um mistério a ser acolhido e absorvido pelo sujeito, a fim de fazê-lo criar novas conexões entre pensamentos para poder assimilá-lo.

médio prazo, transmutadas em números para poderem ser registradas, tratadas, difundidas, conservadas, manipuladas: o destino da imagem é daqui em diante numérico. Essas técnicas não podem deixar de interessar artistas à procura de novas experiências e de novas investigações perceptíveis." (COUCHOT, 1993, p. 45). 
Há a limitação do próprio meio, pois a maior parte dos serviços disponibilizadores de vídeos da internet ainda opera com um limite de tempo para a exibição. No caso da ferramenta utilizada para assistir aos vídeos na experiência, o site YouTube, a limitação à época era de 10 minutos por vídeo. ${ }^{3} \mathrm{O}$ tempo de exibição, por si só, não traz problemas para a comunicação ser possível. Entretanto, o tempo reduzido traz a possibilidade de ter acesso a muitos vídeos, com conteúdos diversos, em um curto espaço de tempo. Tomemos como exemplo a média de um filme cinematográfico convencional, cujo tempo de exibição costumeiramente gira em torno de 120 minutos; nesse mesmo espaço de tempo, é possível assistir a 12 vídeos completamente diferentes um do outro, tanto em estilo, como em temática e elementos de produção. Se levarmos em conta que muitos dos vídeos não atingem o limite máximo de tempo, o número pode ser bem maior.

O que pode parecer um grande feito para as pessoas, que agora podem ter acesso a um sem número de vídeos sem sair de casa, pode trazer também um empobrecimento da experiência. Um vídeo isolado, independentemente de sua duração, é capaz de conter os elementos para criar uma relação com o sujeito que leve à comunicação. A questão é que a quantidade de vídeos, que se acumulam um após o outro, acaba por saturar o expectador, a ponto de não mais tocá-lo. O fenômeno não se completa, não se chega à comunicação.

A problemática da quantidade nos meios de comunicação já foi apresentada sob diversas formas pelos mais variados autores. Vejamos por exemplo uma passagem de Jean Baudrillard a esse respeito:

Em toda a parte a socialização mede-se pela exposição às mensagens mediáticas. Está dessocializado, ou é virtualmente associal, aquele que está subexposto aos media. Em toda a parte é suposto que a informação produz uma circulação acelerado do sentido, uma mais-valia de sentido homólogo à mais-valia econômica que provém da rotação acelerada do capital. A informação é dada como criadora de comunicação, e apesar do desperdício ser enorme, um consenso geral pretende que existe, contudo, no total, um excesso

3 Embora mais recentemente, no dia 29.07.20010, foi anunciada a ampliação do limite de tempo para 15 minutos, esse ainda se mantém como um limitador importante. O anúncio foi feito pelo blog oficial do serviço no endereço: http:/ / youtube-global.blogspot.com/2010/07/upload-limit-increases-to-15-minutes.html. 
de sentido, que se redistribui em todos os interstícios do social [...]. Somos todos cúmplices deste mito. É o alfa e o ômega da nossa modernidade, sem o qual a credibilidade da nossa organização social se afundaria. Ora o fato é que ela se afunda, e por este mesmo motivo. Pois onde pensamos que a informação produz sentido, é o oposto que se verifica. A informação devora seus próprios conteúdos. Devora a comunicação e o social. (BAUDRILLARD, 1991, p.104-5)

O processo apresentado por Baudrillard foi potencializado ao extremo com a internet. $\mathrm{Na}$ atualidade, a quantidade de dados é imensamente maior e a acessibilidade a eles foi grandemente facilitada. Há a expectativa de que, por ser possível acessar tudo, temos o dever de assim proceder. Criou-se a necessidade de se utilizar da possibilidade do acesso no lugar em que antes tal não era sequer imaginada. Essa necessidade foi construída, arquitetada, pelo próprio desenvolvimento tecnológico que fez com que desenvolvêssemos a utilidade prática para a possibilidade de acesso.

Pela experiência metapórica empreendida por mim, infere-se que a grande quantidade de vídeos não só não contribui, como atrapalha na qualidade da experiência. A capacidade de assimilação do sujeito para uma experiência sofisticada como a comunicação é limitada e requer um preparo anterior. Além disso, ao provocar o sujeito a pensar, o fenômeno exige o mínimo de tempo de respiro para as conexões formarem novas possibilidade de pensar e darem asas à ação criativa. O ritmo acelerado dos vídeos e sua imensa quantidade faz com que não haja qualquer tempo para uma reflexão sobre aquilo que é assistido. Um vídeo que poderia suscitar um baque que traria uma possível nova ideia logo é atropelado por outro, não deixando espaço para criar um laço entre ao que se está exposto e o que já temos conosco anteriormente.

O movimento de ideias que traria a possibilidade do novo nunca é de fato posto em prática, pois o ritmo é tão intenso que mal se incorporou um dos objetos, já se é desafiado por outro, em um encadear sem fim, que não traz a possibilidade de nada novo surgir. A sensação é de que você é preenchido por todas aquelas imagens, mas elas passam por você em uma velocidade tão que não é possível acolhê-la. Por mais que você lute e coloque toda sua intencionalidade na busca de sentir o objeto, ele te escapa e logo é substituído por outro. 
Simultaneamente, surge uma sensação de frustração, como se sua consciência quisesse mais. Cada novo vídeo reacende sua expectativa, mas logo é atropelado por outro, e a busca parece não ter fim. Ao final do processo, sente-se uma frustração, porém uma imensa necessidade de empreender mais uma tentativa, de tentar mais uma chance nesse jogo das imagens. 


\section{Capítulo 2 O encanto}

Pelo que foi constatado através da experiência metapórica, da relação entre o ser humano e as imagens contemporâneas não é possível se chegar ao fenômeno da comunicação. A raiz dessa impossibilidade pode estar presente logo no início da formulação da hipótese. Vejamos: para ocorrer a comunicação, os dois (ou mais) lados envolvidos devem estar em condições semelhantes, tanto de disposição para se entregar ao processo, como em relação à força que cada um dispõe na situação. Ou seja, os lados envolvidos devem estar abertos e em condições iguais para que haja a possibilidade do Acontecimento comunicacional ocorrer.

A relação de forças envolvidas do fenômeno da comunicação se aproxima às regras de um jogo: os participantes devem possuir condições semelhantes em seu início, cabendo a cada um, pela sorte e/ou pela astúcia em lidar com os obstáculos apresentados, destacar-se e galgar os passos para uma vitória. No caso de um dos participantes ter uma situação privilegiada, toda a situação é afetada, pois o embate de forças não será justo, o que quebra o acordo tácito de todo jogo de dar iguais condições. Ou seja, um jogo, para entreter de maneira semelhante os vários lados envolvidos, deve colocar os jogadores em um mesmo patamar, em que a balança de forças não penda, logo de início, para um dos lados opostos, configurando uma clara desvantagem.

Vejamos o que ocorre na relação entre o ser humano e as imagens. Quando eu me coloquei diante dos vídeos da internet, minha intencionalidade estava voltada para proporcionar uma interação entre minha consciência e as imagens. Com isso, o esperado era conseguir criar um vínculo tal que fosse possível me deixar dissolver pelo outro participante, em uma busca 
de fusão completa. No entanto, a partir de um determinado ponto, percebe-se que a relação de forças entre os participantes é desigual: as imagens são as responsáveis por todo o encaminhamento do jogo e de ditar as regras. Tal fato é evidenciado pelo encadeamento dos vídeos, em que um se sobrepõe ao outro de maneira a propiciar quebras, que não permitem uma completa fusão com o objeto. Com isso, nunca se chega a uma completa imersão, pois a cada mergulho você é empurrado para trás e é tragado novamente pelo próximo.

Os vídeos possibilitam uma imersão muito breve, logo interrompida por uma brusca quebra, levando a uma dispersão instantânea; em seguida, você é tragado novamente pela vaga do próximo vídeo, e esse movimento se mantém durante todo o período de exposição. É um eterno movimento ritmado de imersão e dispersão proposto pelos vídeos, o qual não permite haver uma interação de qualidade mais profunda como o exigido para haver a comunicação. Os motivos para esse movimento podem ser identificados tanto no próprio objeto como no meio em que ele é apresentado.

Os vídeos disponíveis para visualização são de uma variedade técnica muito grande. A questão não é somente a narrativa de cada um que, mesmo ao abordar um mesmo assunto, varia de um para o outro. As variedades de equipamentos utilizados, as várias formas de edição, as diversas técnicas de fotografia e enquadramentos, entre outros, são responsáveis pela diversidade dos vídeos. O que pode ser tratado como uma grande qualidade, no caso da comunicação não é muito produtiva, pois não permite que você interaja com os vídeos e que eles repercutam em você.

A variedade dos vídeos é potencializada e estimulada pelo meio, no caso, a internet. Ela funciona como uma grande plataforma de conteúdos variados que, ao mesmo tempo em que facilita a distribuição desses conteúdos, também estimula sua produção, por justamente garantir a possibilidade de serem vistos. Aliás, essa é a grande promessa que parece emergir da internet: veja e seja visto. As possibilidades do meio tornaram-se um imperativo no sentido de criar a necessidade de se produzir imagens em larga escala, já que há a oportunidade de sua visualização por milhões de pessoas ao redor do planeta. Sobre isso, destaca-se o comentário apresentada por Dietmar Kamper e Norval Baitello Junior:

A esperada paz trazida pela informação e pela mídia não ocorreu. Em seu lugar impera uma selvagem guerra das imagens que ain- 
da nem atingiu seu ápice. O olhar controlador, agora onipresente, obriga as pessoas a se transformar em uma imagem que não transborde para fora das molduras previstas e que satisfaça às exigências de uma visibilidade em ascensão. Tudo o que não for visível tem que ser descartado como objeto sem valor, antes mesmo de entrar no jogo. Em compensação, toda imagem conformável ao olhar pode ser configurada ativamente, apresentada e reapresentada em encenações repetidas uma vida inteira, inclusive com a participação das pessoas que se colocam sob os olhares controladores. (2000, p.7)

A necessidade de se produzir imagens em busca da perpetuação de uma vida finita ganhou um grande aliado com o advento da internet. Tornou-se impossível não documentar um momento, já que os meios para fazê-lo são já acessíveis para boa parte da população e, além disso, a possibilidade de distribuição é infinita e sem precedentes na história humana.

Por conta disso, a quantidade de vídeos a serem visualizados é imensa e a necessidade de vê-los lhe é proporcional, afinal, abster-se de assistir aos vídeos equipara-se a não participar do próprio movimento da sociedade contemporânea engajada em sua ânsia por documentar e apresentar tudo. E a disposição em que eles são apresentados também contribui para uma visualização mais longa, pois após o primeiro lhe são sugeridas algumas dezenas de opções de outros vídeos relacionados ao que acabou de ser visto. Ou seja, o que começa pela visualização de um vídeo raramente se resume a apenas um.

A imensa quantidade de vídeos, seu encadeamento ritmado entre imersão e dispersão e a necessidade de assisti-los parece apenas ser benéfico para as imagens nesse jogo. A impossibilidade de haver comunicação no processo parece fazer com que a busca por algo mais profundo atice ainda mais a necessidade de assisti-los. A sensação ao ficar exposto para os vídeos era a de incompletude, como se algo faltasse. A consciência humana parece buscar algo mais significativo, que a desafie e obrigue a pensar. Como essa necessidade não é suprida, o usuário sente-se compelido a continuar a busca, mesmo sem saber o que buscar exatamente. O resultado é sempre frustrante, entretanto não impede que se continue a tentativa em outras rodadas de vídeos.

O jogo das imagens contemporâneas opera-se, portanto, por meio de uma espécie de encanto: elas apresentam uma possibilidade de se entrar em contato com uma experiência mais 
significativa, de se fugir de uma existência banal, tanto para quem produz como para quem assiste. Para o produtor, a imposição de criar e disponibilizar rapidamente, aliado ao aspecto facilitador e automático dos equipamentos, faz com que muitas vezes ele não consiga produzir algo que vá além do senso comum, do já dado e existente, e fique preso em uma masmorra de modelos com a sensação de não poder criar algo realmente surpreendente e novo. O espectador, que parte em busca de uma situação que lhe proporcione uma experiência que expanda os limites do seu mundo particular, acaba preso na eterna busca pelo Acontecimento transformador, que lhe provoque o pensamento.

As imagens, no contexto de um meio multiplicador como a internet, parecem não conseguir ir além de sinais emitidos, os quais apenas servem para excitar nossos sentidos. Parece não haver sentido possível em um meio que proporciona tanto o excesso de estímulos como a internet. Para Jean Baudrillard, o que há é uma implosão do sentido nos meios:

Numa palavra, Medium is message não significa apenas fim da mensagem mas também o fim do medium. Já não há media no sentido literal do termo (refiro-me sobretudo aos media eletrônicos de massa) isto é, instância mediadora de uma realidade para uma outra, de um estado do real para outro. Nem nos conteúdos nem na forma. É esse o resultado rigoroso da implosão. Absorção dos polos um no outro, curto-circuito entre os polos de todo o sistema diferencial de sentido, esmagamento dos termos e das oposições distintas, entre as quais a do medium e do real - impossibilidade, portanto, de toda a mediação, de toda a intervenção dialética entre os dois ou de um para o outro. Circularidade de todos os efeitos media. Impossibilidade de um sentido, no sentido literal de um vetor unilateral que conduz de um polo a outro. Há que considerar até o fim esta situação crítica mas original: é a única que nos resta. (1991, p.108)

A dispersão causada pela quantidade de dados, textos e, como no objeto estudado, imagens não permite que algo mais significativo ocorra. As imagens, nesse contexto digital, surgem apenas como uma sequência de pontos luminosos capazes de nos encantar e nos levar a acompanhá-las, mas não são capazes de fazer nada além disso. A velocidade e o ritmo com que surgem tem o poder de entreter, de manter a atenção, entretanto não nos tocam. 
As imagens, por si sós, já possuem um elemento do campo da magia. Dietmar Kamper (2002, p.2) diz que a imagem ainda apresenta elementos da magia de seus primeiros anos, quando era encarada como a plena presença daquilo que ela representaria; mesmo com a passagem para a ordem da representação, em que ela começa a ser encarada apenas como semelhante ao seu objeto, ela ainda mantém traços do sagrado, como nas representações utilizadas em ritos religiosos.

A imagem é sempre abstrata, no sentido de não existir por si só; ela só existe para representar algo que não ela mesma. Essa imaterialidade da imagem lhe confere uma característica muito particular, de ser ao mesmo tempo ausência e presença. Sua presença vai além da materialidade do aparato utilizado em sua manifestação, ou seja, ela é ao mesmo tempo o suporte utilizado (papel, tela) e algo a mais, a ser completado com a percepção.

Tal característica abstrata da imagem encanta o homem. A imagem nos é sempre misteriosa e faz com que sempre tenhamos interesse em desvendar o mistério da ausência e da presença proposto por ela. No caso dos vídeos da internet, aliado a esse fator do mistério está a questão do excesso do meio e as implicações que isso traz para uma interação mais profunda com a imagem. Diria Baudrillard (1991, p.109) que "Para além do sentido, há o fascínio, que resulta da neutralização e da implosão do sentido", ou seja, no caso do excesso trazido pelos meios, a imagem perde o sentido, o elemento mais irredutível, "este incorporal nas superfícies das coisas, entidade complexa irredutível, acontecimento puro que insiste ou subsiste na proposição" (DELEUZE, 2007, p.20).

A imagem, no contexto contemporâneo, perde seu elemento deflagrador da criatividade, sua energia espontânea, e reduz-se à abstração mágica. Tal fato é causado pelo excesso, em que a profusão é tamanha que não se é mais capaz de ir além e buscar o sentido. O que nos sobra é o encantamento, que nos mantém fiéis à sua magia em busca de um sentido para tudo aquilo. Talvez por isso seja tão difícil deixar de apreciar as imagens e sempre volta-se a buscá-las: estamos sempre na busca de um sentido, que aparentemente elas poderiam nos apresentar, mas que nunca atingimos.

A sensação relatada na experiência metapórica é a de vazio. Talvez esteja intimamente relacionada a essa perda do sentido em detrimento do excesso oferecido pelo meio. Por mais que 
se busque, parece que nunca se está saciado com a procura, não há uma plenitude do processo. Persiste sempre o sentimento de que algo está faltando. “Tendo em vista que quase ninguém é capaz de resistir ao horror vacui (medo do vazio), daí deriva a sucessão circular de substitutos que procura supri-los com uma aceleração crescente de substituição" afirma Kamper (2002, p.3) a respeito da profusão acelerada de imagens na contemporaneidade. Podemos entender, portanto, que o movimento é bilateral e contínuo: ao passo que a tecnologia incita e facilita a produção e a distribuição de imagens, provocando o excesso, no outro extremo o homem, compelido a assistir a todo o material disponível, não se satisfaz com o que lhe é oferecido e busca cada vez mais as imagens para tentar preencher seu vazio de sentido para as coisas.

O ser humano está rodeado por imagens contemporâneas, mas não sabe o que fazer com elas. A compulsão de consumir dados, seja em forma de textos ou imagens, aumenta na proporção em que as experimentamos. E quanto mais as experimentamos, menos conseguimos extrair dela alguma vivência que nos acrescente, que aumente nossa complexidade. É como se em vez de imagens estivéssemos dentro de um quarto espelhado, em que vemos apenas reproduções de superfícies conhecidas sobre reproduções distorcidas daquelas e nada pudesse realmente nos tocar ao ponto de provocar algum pensamento criativo.

O encanto também opera para dificultar a constatação de toda essa situação. Quando se está no processo, é difícil perceber o que ocorre de fato. As imagens, apoiadas pela tecnologia, estão de tal forma presentes em nosso cotidiano que sequer nos damos conta de sua presença: elas simplesmente estão lá. Sua visualização é tão facilitada e encorajada que é vista com estranhamento qualquer posição contrária a sua utilização. Devido aos benefícios trazidos pelos avanços tecnológicos, usa-se da tecnologia com a esperança de que ela traga um alento para a vida.

No caso das imagens, o encanto possui uma característica muito específica: devido a sua imaterialidade, a imagem é completada por nossa percepção. Para que isso aconteça, ela precisa atingir nosso cérebro para ser retrabalhada por ele para se tornar reconhecível. Esse fato mostra a eficácia das imagens para atingir nossa consciência e trabalhar em conjunto com nossa percepção. Mas é preciso aprofundar um pouco mais para entendermos o grau de interferência que as imagens contemporâneas são capazes de atingir em nossa consciência. 
Em 2001, um estudo norte-americano desenvolvido pela Universidade da Califórnia (SCHWITZGEBEL, 2003) refez um questionário aplicado primeiramente em 1942, cujas perguntas giravam em torno dos sonhos: se as pessoas tinham com mais frequência sonhos em preto e branco ou em cores. No estudo primordial, 70,7\% dos entrevistados relataram que raramente ou nunca viam cores em seus sonhos. Na pesquisa feita em 2001, apenas $17,7 \%$ dos entrevistados afirmaram raramente ou nunca sonhar em cores.

Como é sabido, em 1942 não havia nenhuma técnica de produção de imagens fotográficas ou filme em movimento em cores. Apesar de não conclusivo, os dados apresentados pela pesquisa corroboram para a ideia de que as imagens contemporâneas podem sim afetar nosso cérebro em níveis intensos, a ponto de influenciarem não só os conteúdos, mas a forma com que são elaborados os sonhos. ${ }^{4}$

A interferência que as imagens podem ter em nosso cérebro ainda é pouco conhecida, mas pode-se inferir que boa parte de nossa noção de realidade é preenchida pelas imagens que temos acesso pela televisão, pelos veículos impressos e, mais recentemente, e com grande intensidade, pela internet. Para avançarmos nesse aspecto, é importante delimitar a noção de realidade; a utilizadada nesta dissertação é baseada no filósofo Gilles Deleuze, com base em conceitos de Henri Bergson sobre o objetivo (ou matéria) e o subjetivo (ou duração):

[...] um objeto pode ser dividido de uma infinidade de maneiras; ora, mesmo antes de tais divisões serem efetuadas, elas são apreendidas pelo pensamento como possíveis, sem que nada mude no aspecto total do objeto. Portanto, elas já são visíveis na imagem do objeto: mesmo que não realizadas (simplesmente possíveis), tais divisões são atualmente percebidas, pelo menos de direito. [...] Bergson quer dizer que o objetivo é o que não tem virtualidade - realizado ou não, possível ou real, tudo é atual no objetivo. [...] Em resumo, chamaremos objeto, objetivo, não só o que se divide, mas o que não

4 Outro pesquisa interessante sobre o tema, dessa vez da Universidade de Dundee do Reino Unido, foi realizada entre pessoas com menos de 25 anos e com mais de 55. Para o grupo com até 25 anos, somente 4,3\% dos sonhos eram em preto e branco. Os maiores de 55 anos que tiveram acesso a TV em cores na infância também apresentaram um baixo percentual de sonhos em preto e branco: 7,7\%. No entanto, daqueles com mais de 55 anos que só tiveram acesso a TV em preto e branco na infância, 25\% dos sonhos eram em preto e branco. (MURZYN, 2008) 
muda de natureza ao dividir-se. É, portanto, o que se divide por diferenças de grau. (DELEUZE, 1999, p. 30)

Na verdade, a duração divide-se e não para de dividir-se: eis por que ela é uma multiplicidade. Mas ela não se divide sem mudar de natureza; muda de natureza, dividindo-se: eis por que ela é uma multiplicidade não numérica, na qual, a cada estágio da divisão, pode-se falar de "indivisíveis". Há outro sem que haja vários; número somente em potência. Em outros termos, o subjetivo, ou a duração, é o virtual. (DELEUZE, 1999, p. 31-2)

A partir do movimento processual entre um plano de linhas de forças operantes nos mínimos eventos - o virtual - e tudo o que perdura o suficiente para ser captado por nossos sentidos formas, matérias, coisas, ou seja, o atual -, torna-se possível a percepção de uma realidade objetiva; o virtual, espaço da conservação do passado e da imanência, é também o das multiplicidades, das quais o atual, espaço da passagem do presente, "atualiza" uma, dando-lhe caráter de realidade. Ou seja, as coisas como elas se mostram são uma forma de atualização do virtual.

Diante disso, podemos considerar a realidade como uma construção, em que participam o ser humano, sua percepção, suas experiências interiores e os objetos. Levando-se em conta que boa parte de nossas experiências são advindas do contato com imagens, podemos concluir que parte substancial de nossa realidade é formada com a participação delas.

Mas que tipo de realidade construímos a partir das imagens contemporâneas? Para chegarmos a esse ponto, vamos analisá-las brevemente. As imagens, por serem uma abstração, apenas captam uma parte do objeto. Pensemos em uma cena de um diálogo entre dois participantes: além dos aspectos visuais, há toda uma riqueza de sensações que podem advir daquele momento: os estímulos táteis e olfativos, a vibração das duas pessoas em interação e o clima da cena (como exemplo, a clara sensação que o ar está pesado em um ambiente em que os sentimentos entre as pessoas não são os mais amistosos). Todas essas dimensões da cena são perdidas e o que resta são os aspectos visuais e sonoros.

A tecnologia tenta a todo custo suprir essas ausências, desenvolvendo cada vez mais os recursos visuais e sonoros. Atualmente, o avanço nesses campos já é tamanho que muitas vezes as imagens são muito mais detalhadas e o som é muito mais nítido que se fosse captado por um 
simples ser humano e seus antiquados órgãos dos sentidos. Diante disso, o homem contemporâneo delega essa função à tecnologia.

Ao excluir da cena todos os outros aspectos, as imagens apresentam um mundo mais colorido, sem odores desagradáveis e sem a imprevisibilidade do contato presencial com o outro. Elas apresentam um mundo asséptico, em que mesmo as atitudes mais controversas podem ser estetizadas. Esses elementos dão base para a construção de uma realidade muito particular: uma realidade radical.

A realidade radical das imagens apresenta um mundo em que a alteridade não passa de mais um entre diversos elementos de cena. O outro ser é reduzido a simples adorno; sua presença, outrora poderosa e carregada de energia presencial, passa a ser dispensável. A relação com o mundo passa a ser contemplativa, de expectador, e não de partícipe.

A realidade radical não permite que o humano possa participar dela, possa alterá-la. Ela aparece pronta, não exige muito esforço por parte do expectador para se presentificar. Ao homem, resta apreciá-la e aceitá-la. Ela tira de todos nós a atitude ativa de modificar e nos coloca na posição de apreciar.

As consequências da realidade radical formada pelas imagens podem ser sentidas indiretamente no conjunto social. Uma das principais características da sociedade contemporânea é a acomodoção e a procura por prazeres sem muito esforço. Em que pese outros fatores, parte se deve à própria constituição da sociedade, na qual o homem foi retirado de seu papel de atuante para o de mero expectador. Ou seja, o homem e suas atitudes, ao deixarem de ser o motor que movimenta a História, passam a não mais ter o poder de alterá-la. Além disso, as imagens oferecem uma alternativa mais simples e direta para o prazer, não um prazer participativo, mas um contemplativo e solipsista.

A realidade radical é o ápice do encantamento das imagens. Essas são o elemento mais bem acabado do processo de alienação do humano pela tecnologia, pois além de ser apresentadas como um elemento facilitador da vida cotidiana, principal argumento tecnológico para se inserir no social, elas possuem ainda o elemento do mistério, do mágico, ou seja, a capacidade de estar presente e ausente em simultâneo. Com isso, são incontestáveis, pois sua atuação é ainda mais imperceptível no emaranhado do cotidiano e suas interrelações. 


\section{Capítulo 3}

\section{O entorpecimento}

Durante a experiência metapórica com as imagens contemporâneas, uma sensação constante era a de inércia. Há uma clara dificuldade em se sair da situação de prostração diante da tela assistindo aos vídeos. As imagens que são apresentadas possuem a capacidade de envolver de tal maneira que se chega ao ponto de sequer questionar o seu estado, ou seja, perde-se momentaneamente a capacidade de se elaborar um pensamento crítico com vistas a questionar a própria situação. Por alguns instantes, esquece-se da própria condição de existência.

Experimenta-se com as imagens uma sensação de torpor. Há uma diminuição da sensibilidade e dos movimentos em favor de uma posição inerte e contemplativa. A diminuição da sensibilidade engloba não apenas o enfraquecimento dos sentidos do organismo, com a perda da noção espacial, mas também da capacidade de ser sensibilizado pelos conteúdos, de se deixar ser tocado pelo que é apresentado. Como relatado na experiência, a exposição aos vídeos tornou-me mais fechado, levando a uma diminuição da minha capacidade de comoção e empatia, elementos que proporcionam a possibilidade de comunicação com objetos culturais.

A diminuição dos movimentos é inerente ao processo, por ser necessário prostrar-se diante da tela. Entretanto, essa posição já traz em si em elemento impositivo de submissão: tira-se do homem o prazer do movimento, que envolve todos os sentidos, em benefício de um prazer visual e auditivo. Além disso, colocar-se em movimento muitas vezes representa explorar o mundo e entrar em contato direto com outras pessoas, com toda a riqueza de um encontro presencial. 
Diante de tal situação, a questão que se apresenta é qual o motivo que leva o homem contemporâneo, entre tantas outras possibilidades, a se colocar em frente a uma tela e ali gastar boa parte de seu tempo. Ou seja, deve-se procurar entender quais os instrumentos que as imagens possuem que as fazem ter essa característica tão forte de captura da atenção e de domar os instintos humanos de movimentar-se.

A resposta a tais questionamentos está na própria sensação provocada. O torpor é uma sensação causada por um agente entorpecente, no caso as imagens. Elas possuem o poder de entorpecimento, de provocar a apatia dos sentidos e de colocar o indivíduo que está em contato com elas em uma situação de dependência.

O entorpecimento promovido pelas imagens é tão poderoso quanto sutil. Durante todo o processo de visualização dos vídeos, tal característica evidenciou-se somente pela atenção voltada a todas as sensações do momento, ou seja, é muito difícil identificá-lo em situações cotidianas. Ele pode se confundir com o cansaço; mas se fosse esse o caso, a reação seria a de repelir a experiência, pois demonstraria o desinteresse no procedimento. De forma diversa, a sensação apenas faz com que você permaneça mais tempo a vivenciando.

As imagens possuem uma característica mágica, a qual provoca o encantamento. Está aí a origem do entorpecimento. Mas também está no próprio meio, no caso a internet, que, ao propiciar a multiplicação sem limites, potencializa tal característica. Portanto, o meio digital parece ser o ambiente ideal para que todo o mecanismo do encanto se manifeste e culmine no entorpecimento.

O processo de entorpecimento pode ser caracterizado como tal por intermédio de três etapas. A primeira é a do encanto. Como já apresentado no capítulo anterior, as imagens, por meio do mistério inerente a elas, cativam o homem e o transformam em seu adorador. Esse é o momento em que se é tragado pelo turbilhão de imagens e perde-se a noção da existência ali naquele momento.

A letargia é a segunda etapa e se manifesta na condição de inércia e enfraquecimento do ambiente exterior no campo de interesse. Como apresentado no relato metapórico, esse momento é similar a um transe, no qual se é levado a um estado de perda momentânea da consciência de si mesmo. Os sentidos se enfraquecem em detrimento da visão; entretanto, mesmo 
ela não possui um papel atuante, pois os olhos tornam-se apenas um canal para a entrada das imagens e perdem a autonomia de selecionar os objetos para fixar a atenção.

Nessa etapa, as sensações corporais não são mais sentidas. Como exemplo, o desconforto de permanecer um longo período na mesma posição não chega a incomodar a ponto de se desejar o fim da experiência. O corpo fica anestesiado em prol da captação de todos os estímulos visuais. Sente-se vencido pela inércia e não há forças para sair de tal posição.

Além disso, os próprios pensamentos se esvaem em meio às imagens que tomam a mente. Há uma sensação de incapacidade de ligar as ideias e de formular algum pensamento inovador. No entanto, tem-se a plena convicção de que se está ativo no processo, pois os estímulos são tantos que o expectador sente como se estivesse em formulação de algum conceito. O que não passa de um grande equívoco, pois embora a mente esteja cheia de dados vindo das imagens e em plena atividade cognitiva, ela é incapaz de desenvolver qualquer ligação entre eles ou entre eles e algum outro conceito já existente. Ou seja, é como se estivesse vazia. O que se tem é a força que mantém o corpo e a mente inertes naquela situação.

A terceira etapa do entorpecimento se dá quando se resolve interromper o processo. É quando se sente as consequências do ocorrido, tanto físicas quanto mentais. Da parte física, há uma sensação de forte tontura ao final da experiência. Levando-se em conta a alta carga de estímulos recebidos pelo cérebro, não é de se estranhar que haja essa consequência. Além da tontura, há um outro componente mais sutil, mas não menos importante. Ao final da experiência, perde-se a capacidade de concentração, tornando uma simples tarefa, como a de ler um texto mais profundo, algo extremamente difícil. Talvez seja resultado da própria fadiga mental, mas é importante destacar que mesmo após um período de descanso, que leve ao sono de fato, ainda sim permanece a incapacidade de concentração. Tal desconcentração passa lentamente com o tempo, mas exige um grande esforço por parte do indivíduo para ultrapassar esse obstáculo. Obstáculo esse que foi mais facilmente percebido devido à atenção a todas as sensações do processo, por se tratar de uma pesquisa, mas que poderia muito bem passar despercebida em condições cotidianas e, por consequência, muito mais difícil de ser ultrapassado.

O longo período de estímulo visual demanda uma alta carga de atividade cognitiva, a qual pode levar à fadiga mental. Estudos recentes revelam que a fadiga mental interfere até 
mesmo no cansaço físico (MARCORA, STAIANO \& MANNING, 2009), portanto não é se se estranhar que possa interferir na própria atividade cerebral. A concentração é uma atividade das mais complexas, pois exige que a atividade cognitiva esteja voltada para um objeto específico; um estímulo prolongado, disperso e rico em detalhes, como o visual, estabelece uma espécie de rotina caótica nas ligações neurológicas (CONSTANTINESCU, 1997), o que dificulta a volta a um modelo mais ordenado e central como o exigido pela concentração.

As imagens e o próprio meio digital contribuem para o efeito entorpecente das imagens. Tal condição torna o homem contemporâneo refém de um vício obscuro e difícil de ser percebido. A própria sociedade encoraja a adesão a esse vício, na medida em que exige de seus participantes um total comprometimento com a atualização, tanto no que diz respeito a informações, como no tocante ao uso de novas tecnologias.

Levando-se em conta o poder que a tecnologia possui, do qual as imagens contemporâneas fazem parte, de substituir aspectos da vida cotidiana do homem por aparelhos ou procedimentos mediados por ela, constata-se que elas, com sua característica entorpecente, fazem parte de um processo mais amplo. Vejamos uma contribuição teórica a esse respeito:

Depois de séculos de uma prática decisiva da visibilidade é que puderam assumir seu trabalho as máquinas de imagem e as máquinas de olhar. Elas apareceram, desde o princípio, não como instrumentos e ferramentas, mas como projetos de mundo com ambições totalitárias. Em vista de sua função social aumentou a expectativa de que se pudesse promover a humanização do homem como pacificação de sua natureza violenta. Aparece, contudo, muito logo uma ambivalência fundamental que perdura até hoje. No plano tecnológico, a sedimentação descrita acima consiste dos seguintes recursos: obrigou-se e obriga-se o homem à posição sentada sem a menor consideração, tendo empregado e ainda empregando, como calmantes, todos os recursos e meios disponíveis (de comunicação e entretenimento, de informação e de ritualização) para se criar uma relação de dependência, usando-os indiscriminadamente como drogas legais (H. Pross). As consequencias são imprevisíveis. De um lado, o poder político e econômico e, de outro, a impotência das pessoas individualmente foram tão enganchados um ao outro que a 
esperança de uma diminuição da violência levou exatamente ao seu oposto, sua intensificação. E as causas exatas disto continuam totalmente obscuras. (KAMPER \& BAITELLO JUNIOR, 2000, p.7)

As imagens, segundo se deprende desse trecho, estariam contidas em um processo mais amplo de tornar civilizado o homem e seus instintos mais primitivos. Tal processo faz parte do projeto moderno, iniciado no Iluminismo, cuja intenção era colocar o homem no centro das discussões. A tecnologia entrou nesse processo como a solução para liberar o homem do trabalho braçal e, assim, fazer com que ele pudesse gastar seu tempo com estudos e reflexões.

No entanto, a promessa de liberar o homem do trabalho não se consumou com a tecnologia: ao contrário, cada vez se trabalha mais, devido a velocidade com que os processos produtivos passaram a ser realizados, o que leva a se produzir mais no mesmo espaço de tempo. Essa expectativa de velocidade torna os homens escravos da produtividade, ceifando o tempo que a eles restaria para as atividades reflexivas.

Como a manutenção do sistema produtivo exige que o homem permaneça inerte em sua posição de trabalho, criou-se subterfúgios para que continuasse sob dominação. A tecnologia foi utilizada com tal objetivo, ao trazer o lazer do homem para essa condição sentada, tornando nebuloso os limites entre trabalho e prazer. Ou seja, domesticado também em seu tempo livre, o homem tornou-se uma presa fácil para a manutenção dos interesses do sistema de produção.

Nesse sentido, a característica entorpecente das imagens prestra-se a esse serviço de dominação. Como uma droga, elas viciam o ser humano de tal forma que ele não só permanece sentado nas atividades produtivas como em seus momentos de lazer. Toda a vida do homem, em suma, acaba se limitando a sua interação com as máquinas.

A técnica só permanece relevante ao se transformar a cada instante, criando a necessidade de o homem acompanhá-la, sob o risco de ficar obsoleto. Segundo Flusser, "a intenção programada no aparelho é a de realizar o seu programa, ou seja, programar os homens para que lhe sirvam de feed-back para o seu contínuo aperfeiçoamento" (1998, p.62). Parece mais adequado afirmar que o aperfeiçoamento técnico vem da necessidade do processo tecnológico manter-se relevante, o que leva a distorções como tecnologias desenvolvidas que, após serem lançadas, mostram-se não tão úteis ou mesmo inúteis, pois não apresentam um ganho significativo na produtividade, sendo retiradas rapidamente do mercado. O importante, para a manuten- 
ção do sistema, é que se mantenha a produção, pois a necessidade do produto será decidida por sua capacidade de se tornar um objeto de desejo das pessoas, temerosas de serem atropeladas pelas novidades.

As máquinas, por sua vez, em sua velocidade de transformação, criam a necessidade e o desejo no homem de utilizá-las. Além disso, há o temor de que ao não estar apto a operá-las, elas o substituirão. Para escapar desse medo, ao homem resta se dedicar com afinco para entender os mecanismos e, dessa forma, conseguir extrair da máquina sua melhor produtividade, o que o leva a passar boa parte do tempo lidando com elas.

A questão da técnica também inclui o afastamento do ser humano de seus pares. Ao assumir as máquinas como objetos de obsessão, para entendê-las e melhor utilizá-las, e de prazer, o homem acaba delegando a elas boa parte de sua interação, quando não toda ela. É difícil administrar o tempo, cada vez mais escasso na sociedade contemporânea, entre o culto à técnica e o convíveo com as pessoas. Acaba sendo mais fácil se relacionar apenas com máquinas que com outros humanos, frutos de toda sorte de imprevisibilidades. É mais garantido uma relação com o previsível, as chances de se decepcionar são menores.

Pode-se argumentar que boa parte da interação com a tecnologia da informática, sobretudo pela internet, é feita justamente para aproximar as pessoas, eliminando as distâncias e trazendo a possibilidade para pessoas, que no mundo real nunca teriam a chance de se encontrarem, entrarem em contato. Sobre esse aspecto, pensemos o seguinte: além de não ser possível trazer todos os recursos presentes na cena presencial, a comunicação pelo meio digital, por maior que seja a resolução da imagem e a qualidade do som, não consegue esconder o fato de que, em última análise, a interação é entre homem e máquina. Não há como ter plena certeza, como na presença, de que o avatar digital realmente é comandado por uma determinada pessoa; nem ao menos de que é comandada por qualquer pessoa. Com o avanço da técnica, até mesmo essa participação humana poderá ser suprimida, com os softwares que respondem não somente a comandos como a expressões faciais, por exemplo. Ou seja, torna-se cada dia mais difícil reconhecer a dimensão humana em um diálogo pelos meios digitais.

Além disso, a técnica, ao servir de canal para a interação entre pessoas, acaba por completar seu legado de manter o homem aprisionado, submisso a sua utilização. E, ao apresentar 
qualquer forma de humanidade, ela o faz friamente, não permitindo sentir a energia que emana do outro e que perpassa o ambiente presencial. O outro, no ambiente digital, resume-se a um amontoado de dados, matrizes de cálculos, que o captura e o replica em possíveis infinitos aparelhos. Não parece ser atingível, pelos menos por meio de nenhuma técnica até o momento desenvolvida, chegar-se ao patamar de simular o efeito desconcertante que o outro causa em nós quando de sua presença física. O que resta da alteridade no ambiente virtual se assemelha à ficção, pois não há como diferenciar, em profundidade, uma pessoa de um avatar construído para um game, por exemplo. E, por não acreditar que ele possua sentimentos ou uma vivência fora do ambiente virtual, eu posso aniquilá-lo com um clique. Ou seja, os limites éticos de um diálogo presencial dão lugar à violência sem limites no ambiente virtual. Não há limiar ético nessa interação, afinal, a técnica nivela o humano a um aparelho, que pode ser descartado assim que não oferecer mais o uso apropriado.

A vivência com a tecnologia, neste trabalho representada pelos vídeos disponíveis na internet, portanto, não extrapola os limites da instrumentalização, ou seja, não ultrapassa a relação homem e objeto utilitário. Um objeto com uma utilidade definida difere radicalmente de outro, como um objeto artístico, em que não há uma utilidade aparente e específica. Ao se fechar em sua utilidade, o objeto não apresenta grandes desafios para quem está em contato com ele. No caso das imagens no ambiente virtual do excesso, elas se limitam ao seu papel de, primeiramente, entreter, para depois encantar e entorpecer, criando um vínculo vicioso entre o homem e a máquina.

A grande questão que se apresenta é sobre os limites que uma vivência que privilegie a interação com as máquinas pode trazer para a vida cotidiana. Pelo relato metapórico, evidenciase que após o fim da exposição aos vídeos, houve uma dificuldade para se readaptar ao convívio humano. As pessoas pareciam ameaçadoras e o próprio ambiente externo não era particularmente atraente. As possíveis razões para tais fatos serão analisados na sequência.

A vivência com as imagens apresenta alguns aspectos específicos a serem considerados, dentre os quais se destacam a interação com elas propriamente dita e a interação com o aparelho utilizado como suporte por elas. Indubitavemente, a técnica sempre deve ser levada em conta em análises de imagens que se utilizam dela para se manifestar. No caso dos vídeos, há ainda a questão do medium em que eles são disponibilizadas. 
No tocante à interação com as imagens propriamente dita, a consequência mais marcante é uma inevitável comparação entre elas e o mundo ao redor. Após um longo período de visualização dos vídeos, ocorre uma acomodação estética, no sentido de se acostumar com aquele tipo de registro do mundo. Além do mais, acostuma-se ao registro visual em detrimento dos demais sentidos, o que aguça sua capacidade de detalhamento quanto a cores e formas.

Ao se deparar com o ambiente externo, percebe-se um mundo totalmente diferente: sem as cores vibrantes com as quais se acostumara; sem os detalhes finamente trabalhados pela alta definição, que carrega nos contornos, deixando-os mais delimitados, atraentes e elegantes; sem os sons detalhadamente pensados, ou mesmo captado na cena com alta qualidade e remasterizado posteriormete; e sem a agilidade e a disposição apresentadas nos vídeos.

O que falta ao sentido visual no mundo externo, extrapola nos demais sentidos: odores desagradáveis, toques involuntários em superfícies ásperas, esbarrões em objetos e em pessoas. Toda a ordem e a limpeza que emana dos vídeos não está presente do mundo real caótico. Mesmo um vídeo cujo assunto seja violento ou que apresente a realidade "nua e crua" não escapa do processo de higienização imposto pela técnica. Ou seja, na comparação, o mundo real parece bem menos interessante.

Em relação ao aparelho utilizado como suporte pelas imagens, no caso dos vídeos, é o cumputador. Em geral, a interação com ele na atualidade se dá em uma posição sentada e contemplativa. Mesmo que ele seja utilizado em um ambiente público, procura-se sempre um lugar mais calmo e mais seguro para sua utilização.

Como toda máquina, o computador exige tempo de dedicação para se familiarizar com seus recursos e, mesmo assim, não é possível utilizar todas as suas ferramentas, pois todas foram se reunindo em um só objeto, com o qual é possível trabalhar, estudar, ter lazer e entrar em contato com outras pessoas. Devido a esse tempo, todos acabamos nos acostumando com a postura de nos prostrar diante deles e dificilmente se consegue executar atividades que não sejam por seu intermédio.

Assim como a televisão, o computador possui a capacidade de trazer para seu usuário imagens dos mais remotos cantos do planeta. Com isso, é possível conhecer lugares que, fisicamente, não é possível ir, seja por questões monetárias, logísticas ou de tempo livre para tanto. O 
que o difere da televisão, pelo menos do sistema ainda dominante no Brasil e na maior parte dos países, é a capacidade de deixar a decisão do que assistir nas mãos do usuário e não do programador dos canaus. Os limites para os vídeos são muito mais de ordem legal, o que pode impedir sua disponibilização em determinados sites em favor de outros.

O principal componente da relação homem e máquina é a aparente segurança que essa relação traz. Ao trazer imagens de lugares inóspitos, o computador nos polpa do perigo de chegar a tais locais. Tudo isso feito em um ambiente seguro, à escolha do usuário. Ou seja, a interação com o computador torna a vivência uma experiência mais segura e sem os imprevistos do ambiente externo.

No tocante ao meio utilizado para a distribuição das imagens, a internet representa o mais alto grau evolutivo da técnica na tentativa de acoplar em apenas uma interface as mais diversas necessidades da vida diária. É possível ficar horas navegando pelos mais diversos tipos de conteúdos, o que é incentivado por sua característica interligada, levando de um conteúdo a outro em apenas um clique.

Além disso, a internet, por seu caráter descentralizado, é entrópica por natureza. Ao permitir a disponibilização de conteúdos por qualquer dos seus milhões de usuários, temos que as possibilidades de dados são infinitas e uma ordenação é humanamente impossível. O excesso, no caso dos vídeos, manifesta-se nas várias possibilidades de imagens relacionadas oferecidas para o usuário, que o leva a uma navegação interminável e consume uma considerável parcela de seu tempo. As possibilidades são tantas e os incentivos para se manter atualizado em relação aos vídeos são tão fortes que não resta outra alternativa a não ser se dedicar à tarefa de assistilos. Ou seja, o meio proporciona a variedade, a qual prende o usuário em sua rede e o faz permanecer vasculhando seus caminhos virtuais em detrimento dos reais. E o acesso ao prazer e ao contato está a apenas um clique, livrando as pessoas das decepções que muitas vezes surgem do contato com outras.

Uma visualização prolongada, como a experimentada na experiência metapórica, dá uma amostra do que é uma vivência com as imagens contemporâneas. As imagens, por meio do encanto que possuem sobre os homens, faz com que eles se tornem reféns de uma experiência que pretende adaptar o homem para ser cada vez mais apto para desempenhar seu papel no 
sistema de produção. Do ser humano tem sido retirada a possibilidade de uma vivência mais completa, como a experimentada na interação com o mundo exterior e com as outras pessoas. O culto à técnica atual, representado pela necessidade criada pelo próprio sistema de o homem precisar constantemente se manter atualizado, desde as últimas notícias até o mais recente vídeo cômico divulgado, e pelo vício criado pela utilização de tais tecnologias, dos quais as imagens fazem parte e exercem papel de destaque, devido a sua característica entorpecente, transforma o homem em objeto utilitário para a manutenção da produção. Por sua vez, o homem, moldado pelas características da vivência, a qual tem sido obrigado a experimentar, muda sua atitude em relação aos outros e ao mundo, tornando-se fechado e autossuficiente, não abrindo espaço para o outro. 


\section{Capítulo 4 \\ Fim da caminhada}

Após a realização da experiência metapórica e o desenvolvimento dos entrelaçamentos teóricos, que buscaram aprofundar o relato e promover um diálogo com as teorias já existentes, faz-se necessário elaborar algumas considerações finais. O objetivo não é ter uma conclusão, pois a ideia de todo este trabalho está voltada para a abertura para a discussão, ou seja, apresentar o objeto e descrevê-lo com sinceridade e envolvimento. No entanto, é interessante fazer alguns apontamentos finais, com vistas a ligar alguns pontos e sugerir alguns tópicos a serem desenvolvidos futuramente.

A proposta de encarar a comunicação como um Acontecimento traz a oportunidade de investigar a relação e não o objeto. $\mathrm{Na}$ área de comunicação, é comum o estudo dos meios, mas pouco se olha para o que ocorre entre os envolvidos no processo. Não se trata de pesquisa de opinião de um determinado grupo em relação a um objeto cultural, por exemplo. A intenção é investigar o momento em que ocorre a interação, sentir as sensações instantâneas e transcrevê-las.

Dessa forma, a comunicação é encarada como um movimento, um processo. Trata-se de um objeto de pesquisa fugaz, cheio de energia e vitalidade, e como tal, para ser estudado, necessita de uma abordagem que mantenha seu caráter vivo. As pesquisas tradicionais, em geral, baseiam-se em uma visão cartesiana de dividir o objeto em partes e estudar cada uma separadamente, pois, conhecendo-se cada uma delas, chega-se à compreensão do todo. Entretanto, tratando-se de um objeto imaterial, fugidio e vivo, tal abordagem não parece ser a mais adequada. 
As imagens são objetos culturais e, como tais, são passíveis de provocarem o fenômeno comunicacional. Elas estão onipresentes na sociedade contemporânea e, por sua larga utilização, muitas vezes passam despercebidas. Há uma vulgarização das imagens, no sentido de que elas são produzidas e distribuídas em larga escala por qualquer ser humano que tenha acesso a algum equipamento capaz de criá-las e transportá-las para diferentes formatos. Produz-se imagens sem ao menos ter em mente os motivos para tal procedimento, sem uma razão aparente. O barateamento dos equipamentos fotográficos e de filmagem trouxe o benefício do acesso por diferentes setores da sociedade, dos mais diversos extratos sociais. Para quem produz uma imagem, há a promessa de também ser visto, de ser notado pelas outras pessoas, o que é o ápice existencial em um mundo em que se destacar em meio a tantos outros atrativos é a maior das ambições. Como consequência, vemo-nos a cada dia mais rodeado por imagens, em todos os ambientes e circunstâncias, e queremos fazer parte do processo, em uma tentativa de também sermos vistos. Ver e ser visto se tornou o lema do homem imagético do século XXI.

A promessa de visibilidade apresentada pelos meios traz consigo a necessidade de ser visto, pois a não visibilidade torna-se, no contexto da sociedade tecnológica, a nulidade da existência. $\mathrm{Na}$ tentativa de fugir de tal possibilidade, o homem contemporâneo atira-se na empreitada compulsiva de produzir e distribuir imagens, registrando qualquer momento de sua existência. Deixa-se de vivenciar o momento para eternizá-lo, sem se perceber que por melhor que seja a técnica utilizada, essa não será capaz de trazer todas as sensações daquele instante quando for visualizado. As pessoas são impelidas a produzirem imagens para participarem de um processo que tomou o lugar da própria vida. E para se sentir incluído, consome imagens com igual intensidade. A existência pela e para a imagem parece ser a única possível.

Em contrapartida, a indústria do entretenimento e a imprensa elegem a imagem como principal plataforma para comercializar o prazer e a informação, contribuindo para a produção de mais conteúdo imagético. Com a aceleração dos processos de difusão de dados, sobretudo com o advento dos meios digitais, torna-se necessário manter-se atualizado, já que as mudanças são instantâneas e as novidades não param de surgir a todo instante. A imagem tornou-se, portanto, a principal fonte de informação e entretenimento da sociedade atual. 
O processo de digitalização agravou a situação por dois motivos: por facilitar e baratear a produção, e por permitir que mesmo imagens produzidas em outros processos sejam convertidas em pixels e distribuídas em larga escala. Tem-se acesso a qualquer obra humana e qualquer paisagem natural por meio de imagens. A quantidade é tamanha que excede a capacidade humana de absorver tanto conteúdo e, na tentativa de fazê-lo, perde-se tempo que poderia ser gasto em outras atividades.

Tendo em vista tal contexto, urge pensar a respeito. $\mathrm{Na}$ tentativa de descrever esse processo e, a partir disso, iniciar uma reflexão sobre o tema, torna-se necessário partir para o tipo de investigação como a presente neste trabalho. A abordagem foi justamente tentar relacionar a profusão de imagens e o indivíduo, procurando rastrear a relação entre esses dois polos distintos. É uma reflexão sobre o nosso tempo, sobre o agora, sobre a condição humana nesse momento histórico de hegemonia das imagens.

O homem se relaciona com as imagens diariamente, talvez até mais do que com outras pessoas. Por isso, tentar entender a natureza de tal relação se mostra importante para entendermos o tempo presente. A abordagem desse tema merecia uma atenção especial, pois não se tratava de estudar as imagens em si, nem o meio em que elas são distribuídas, mas sim de captar o que acontecia de tão especial na relação entre o homem e as imagens que o fazia se tornar um admirador inconteste delas, a ponto de se encantar mais com elas do que com o mundo real.

Por ter como objetivo a relação entre o indivíduo e objetos culturais, a possibilidade de fazer uma investigação utilizando o metáporo parece a mais apropriada. O metáporo, um quase-método, rompe com a visão mais clássica de pesquisa e de pesquisador. Ele pressupõe um envolvimento do pesquisador na pesquisa, em que há a possibilidade de ele se utilizar como instrumento para averiguar o processo. Envolver-se na pesquisa é um desafio, pois não deixa de ser uma exposição de seus sentimentos mais profundos. No entanto, por se tratar de um tema tão difícil de ser delimitado pela observação de outras pessoas, torna-se imprescindível mergulhar na experiência e dela extrair o relato mais sincero possível.

Como imagens não faltam para servirem de contraponto para a investigação metapórica, a delimitação se fez necessária para facilitar o momento da exposição ao fenômeno e da transcrição das sensações. Os vídeos disponíveis na internet são emblemáticos da questão da ima- 
gem contemporânea, pois neles estão contidos a maior parte dos tipos de imagens existentes: fotografias, desenhos, animações e filmes. Além disso, são de naturezas diversas, podendo ser provenientes da imprensa, da indústria do entretenimento ou do usuário comum. Nesses vídeos está a síntese da sociedade imagética atual, em sua tentativa de se espelhar nas imagens e delas usufruir como uma continuidade da existência.

A importância de uma abordagem metapórica da questão da imagem é evidenciada ao se analisar a produção teórica existente sobre o assunto. O tema das imagens é muito discutido, mas ainda parece não ter chegado ao ponto de investigar a relação que o homem desenvolve com elas e discutir as possíveis consequências disso. Tendo isso em mente, a tentativa foi a de, ao partir de um caso particular, tentar atingir impressões que sejam reconhecidas pelos demais. Para tanto, a própria linguagem, mais intensamente no relato, foi trabalhada com o intuito de ser mais pessoal e direta, privilegiando as sensações e as primeiras ideias que surgiram, em uma busca incessante de não se deixar levar por um discurso mais rebuscado, que não representasse o pesquisador naquele momento específico.

Através da experiência de visualização dos vídeos, foi possível desenvolver um relato contendo as sensações vivenciadas naqueles momentos. A partir dele, tentou-se fazer apontamentos e proposições, buscando, quando possível, tecer paralelos com outros estudos. Tanto o relato quanto os textos reflexivos complementam-se e juntos tratam da questão de uma maneira que buscou a inovação ao abordar um tema de tamanha complexidade.

Pelo relato, pôde-se chegar ao ponto central: a possibilidade de ocorrer a comunicação em uma relação indivíduo e imagens. As reações apresentadas levam a crer que há um Acontecimento, pois é possível sentir com precisão uma mudança no pensar e no agir. Após a experiência, sente-se que se está diferente que antes de passar por ela. No entanto, para configurar a comunicação, é necessário mais do que isso: a mudança deve ter um sentido criativo, de forçar o pensar e, com isso, propiciar o surgimento do novo.

Evidencia-se no estudo a possibilidade de haver um Acontecimento que não está ligado a um acréscimo qualitativo no ser. Talvez essa seja uma contribuição significativa para a teoria, pois a bibliografia utilizada sobre o tema não vislumbra tal possibilidade. Um evento transformador, mas que leva o ser a se tornar mais fechado e menos criativo, é tão significativo quanto 
o Acontecimento comunicacional, que leva a um aumento da complexidade do ser. É uma experiência profunda, complexa e de interessantes consequências tanto para o indivíduo como para a coletividade.

A comunicação como fenômeno não está presente, mas mesmo assim ainda se trata de um assunto de vital interesse da área de estudo da comunicação, afinal, as imagens, por princípio, sempre são produzidas com o objetivo de, se não for tocar, ao menos apresentar algum dado para o visualizador, o qual pode ou não se utilizar disso para construir um conhecimento. Além disso, a internet, como meio de difusão de dados, tem sido utilizada como principal ferramenta para produzir e distribuir conteúdos, portanto merece ser estudada com o intuito de compreendê-la e, para os pesquisadores envolvidos com a função social e educacional da comunicação, aprimorá-la.

A experiência foi feita por meio de uma exposição por quatro horas contínuas, com a intenção de simular um período médio em que as pessoas costumam se utilizar da internet. Se pensarmos que uma parcela da população mundial trabalha o tempo todo conectada e ainda acessa em suas horas de lazer, podemos deduzir que as horas de navegação podem ser muito maiores. No caso deste trabalho, a opção foi os vídeos, por também trazerem as características mágicas e viciantes da imagem; entretanto, poderíamos tratar de textos que, apesar de possuírem uma outra estrutura e oferecerem outro tipo de relação com o usuário, igualmente estão inseridos no processo de massificação dos conteúdos representado pela internet. Mesmo se trocássemos o meio e optássemos pela televisão, por exemplo, os resultados, se não fossem iguais, estariam bem próximos entre si, pois o sistema televisivo há muito tem operado pela multiplicidade de canais e conteúdos, o que também proporciona uma experiência de excesso. A diferença é que a televisão ainda possui muito conteúdo de maior duração, como filmes, os quais possuem outra característica imersiva; no entanto, mesmo os filmes estão propensos a passarem por quebras - os intervalos comerciais - que também não favorecem uma relação de mais qualidade com o objeto, além do advento do controle remoto e a possibilidade do zapping, algo que mudou drasticamente a maneira de se assistir à TV. Em suma, é difícil encontrar um medium que não seja afetado pelo fenômeno do excesso de dados da contemporaneidade. 
O principal a ser discutido são os motivos de impossibilidade da comunicação com os vídeos disponibilizados na internet. Os vídeos, isoladamente, apresentam material suficiente para garantir uma relação mais profunda com seu espectador. No entanto, a forma pela qual são disponibilizados parece atentar contra sua comunicabilidade. Ou seja, o meio interfere na qualidade da relação.

Da experiência metapórica, pode-se inferir que a causa do fato está relacionada ao excesso de dados disponíveis. As possibilidades são tantas e a quantidade é tão grande que o usuário acaba se perdendo pelas infovias e não chega a criar nenhuma relação mais profunda com as imagens que o leve a ter algum impulso criativo. O excesso de dados parece interferir de forma decisiva na comunicabilidade.

Pode-se argumentar que as futuras gerações, mais habituadas ao ambiente de profusão de dados, serão mais capazes de lidar com essa situação. Não obstante a impossibilidade de se fazer tal inferência a partir dos dados levantados neste estudo, mesmo porque não é o objetivo último dele, o fato é que no presente, para o homem contemporâneo, o excesso ainda não é absorvido. Além do mais, o fenômeno comunicacional, por suas próprias características, não parece ser suscetível a uma simplificação ou um encurtamento do tempo para se estabelecer devidamente.

As imagens ainda acrescentam ao processo características muito particulares. O encanto, que surge desde os primórdios das representações imagéticas, é um componente que contribui para aprisionar o sujeito ao processo. As imagens ainda guardam esse componente mágico de imaterialidade, que prescinde o suporte e une presença e ausência em uma só manifestação. Elas fascinam o homem e o tornam seu refém.

O encanto faz parte do jogo das imagens: elas envolvem com a promessa de tirar o sujeito de sua condição e levá-lo para outro ambiente, outra situação, em uma forma de transcender sua existência limitada. Elas seriam como portais para outros mundos, um passaporte para uma realização maior. No entanto, o jogo de sedução das imagens contemporâneas nunca entrega o prazer final, levando sempre a uma próxima imagem e a um gozo nunca atingido: as possibilidades infinitas tornam a busca em vão, uma eterna quase fusão, ou seja, uma não comunicação. 
Outra característica apontada é o entorpecimento. As imagens possuem o poder de nos levar a um torpor que nos deixa resignados em sua veneração. Tal característica é potencializada pelo excesso, pois se vale de nossa incapacidade de lidar com tamanha quantidade de estímulos visuais, trazendo uma fadiga mental e uma incapacidade de tomar a decisão de interromper o processo, por exemplo. O ritmo incessante com que elas aparecem leva o usuário à letargia, o que o aprisiona ainda mais em seu estado de contemplação.

O homem, encantado e entorpecido pelas imagens, não sabe como escapar delas e faz de tudo para se manter a elas ligado. Em contrapartida, esse contato em demasia com as imagens o faz cada mais fechado, mais inapto ao convívio com seus pares, e o isola cada vez mais em seu mundo. Além disso, tal fechamento também se reflete em uma perda da capacidade de se sensibilizar por outros objetos culturais, nivelando as relações à superficial característica de apreciação distante, sem envolvimento.

É inegável que o homem contemporâneo esteja cada vez mais fechado em si. A falácia de que o ambiente virtual aumentou a possibilidade de comunicação entre as pessoas é facilmente derrubada ao se averiguar a qualidade de tais contatos. Há a possibilidade de se conhecer muito mais pessoas, o que não se reflete em relações mais significativas. O que ocorre é simplesmente uma troca de dados, sem se chegar a um aprofundamento.

A diferença de um contato pela internet de um presencial está no fato de que, em última instância, não se foge de uma relação com uma máquina, ou seja, não se tem a dimensão do outro ser. Essa relação homem-máquina não extrapola a condição guiada pela posse e pela utilidade do objeto, partindo sempre do princípio de que o sujeito está em um patamar superior ao objeto. Tal fato é constatado na impossibilidade de se verificar uma real identificação com um objeto cultural, como um vídeo, mas também pode ser estendida às outras pessoas, já que o princípio da quantidade de possibilidades também é manifestado: não é necessário grande esforço de acolher o outro, pois há tantas contatos disponíveis quanto a paciência em substituí-los. Em um mundo em que a própria imagem do ser está banalizada, a principal luta é para manter a atenção do outro antes de ele acionar o botão de "próximo" e partir para uma nova busca.

As consequências de uma vivência sob os parâmetros do excesso de oferta são apenas vislumbrados neste trabalho, mas é possível fazer algumas proposições. A perspectiva de uma 
oferta sem fim de novos e desconhecidos objetos culturais abre a possibilidade de privilegiar o contato mais superficial com eles, na medida em que é temido perder tempo demasiado com um em detrimento de todos os demais ainda à espera de serem visitados. Do homem é cobrado um grau de conhecimento apenas informativo dos itens já vistos, ou seja, não há esse mesmo tipo de cobrança com relação a uma experiência mais complexa. O importante é não estar alheio ao que todos comentam, o que proporciona uma vivência superficial, em que se preza mais o número de vídeos já assistidos ou de contatos que possui, em vez de se priorizar uma experiência com um grau de sofisticação e envolvimento maiores.

Contudo, não se busca fazer um juízo de valor com relação a esse novo modelo implantado e encorajado pelo meios massificados; o objetivo é simplesmente construir um retrato desse momento e desse novo tipo de relação e, a partir disso, avaliar o papel do fenômeno da comunicação em um mundo marcado por esses aspectos. Será ainda possível pensar em um Acontecimento comunicacional em um ambiente tão propício ao isolamento e às atitudes refratárias?

A comunicação entendida como um processo capaz de abrir espaço para o novo é inerente ao espírito humano. É impossível não pensar na história da cultura humana sem se levar em conta as grandes quebras de paradigmas impostas por ideias novas e revolucionárias a modelos então vigentes. Portanto, o surgimento do novo, em todos os campos do pensamento, faz parte de um processo histórico amplo com vistas ao encaminhamento dos fatos tanto na esfera individual como na social.

No entanto, pode-se constatar em diversos campos do saber, notadamente naqueles envolvidos a àreas criativas, uma discussão acirrada provocada pela constatação de que não há mais o que ser criado de novo e que, daqui para frente, apenas serão desenvolvidos conceitos a partir de pequenas modificações em outros pré-existentes. Respeitando-se as razões apresentadas pelos defensores de tal ponto de vista, esse não parece ser o único caminho possível para a compreensão do momento em que vivemos.

A constatação da impossibilidade de se criar algo novo pode estar intimamente ligada ao fato de sermos constantemente bombardeados por estímulos de diferentes origens. Conforme apresentado e discutido neste trabalho, o excesso de dados ao qual temos acesso e do qual é 
difícil escapar possui o papel de nos fechar em relação ao outro, seja ele um objeto cultural ou mesmo um outro ser. Tal fechamento impossibilita que seja feita uma troca que proporcione um questionamento sobre seus próprios parâmetros e, dessa forma, propicia o surgimento do novo.

O papel do homem contemporâneo, em busca de uma experiência mais significativa e que contribua para a expansão de seu mundo particular, seja talvez o de fazer uma seleção do que realmente o interessa ou do que potencialmente pode desafiá-lo. A ideia é que não se fique apenas no campo dos interesses pessoais, o que limitaria muito a ação e poderia acabar levando à mesma situação de prisão ao já conhecido. O papel da consciência no mundo atual é justamente buscar selecionar, no meio do turbilhão de dados que nos chega a cada instante, aqueles que potencialmente poderiam nos desafiar e nos propor novas formas de pensar.

A vivência em um mundo do excesso deve se aproximar cada vez mais de uma experiência estética, no sentido de privilegiar a fruição dos sentidos para se relacionar aos objetos culturais. Como constatado neste estudo, não é possível ter essa atitude com relação ao todo, por isso o papel cada vez mais importante do sujeito como agente de seleção de conteúdos.

A experiência com as imagens contemporâneas deve se basear nesses princípios, caso o objetivo seja o de buscar uma experiência mais profunda. Manter-se passivo diante do turbilhão de imagens apenas contribui para o isolamento e o fechamento do ser para a possibilidade do novo. É preciso ter um papel ativo na seleção, ao buscar vídeos que nos desafiem e nos tragam uma experiência mais complexa e profunda. Não é uma tarefa fácil, no entanto parece ser a única maneira capaz de possibilitar o fenômeno comunicacional com as imagens.

Aos produtores das imagens também é colocado o desafio de ir além da técnica, ou seja, buscar transcender os limites dos recursos tecnológicos dos aparelhos na tentativa de produzir novas leituras sobre as funções já conhecidas e estabelecidas. A tentativa é a de produzir com uma intencionalidade, não apenas porque é possível fazê-lo. A técnica deve ser utilizada com um propósito além do simples fato de ser possível e acessível.

A relação do homem com as máquinas, no âmbito de um ambiente digital, também pode ser repensada com vistas a se buscar uma experiência mais complexa. É necessário extrapolar a relação homem e objeto no caso da troca de dados com outro ser, buscando uma abertura maior 
e sempre tendo como horizonte de ação o limite da alteridade, na tentativa de se vislumbrar uma identidade além da simples imagem do avatar, com o objetivo de propiciar uma relação ética entre iguais.

O homem na contemporaneidade já nasce envolto pela tecnologia e precisa inevitalvelmente aprender a lidar com esse fato de uma maneira que possa se beneficiar disso. A relação que ele possui com ela, até o momento, tem sido de contemplação e sem colocar limites a sua própria prática. Em busca de uma comunicação que seja possível com as imagens contemporâneas, parece necessário um maior empenho, no sentido de selecionar e não se deixar levar pelo turbilhão imagético. Dessa forma, poderemos buscar um sentido para uma existência na sociedade tecnológica atual. 


\section{Bibliografia}

ADORNO, Theodor. The cultural industry. Nova York, Routledge, 2001.

Indústria cultural e sociedade. 4. ed. São Paulo, Paz e Terra, 2007.

ADORNO, Theodor \& HORKHEIMER, Max. Dialética do esclarecimento. Rio de Janeiro, Jorge Zahar Editor, 1985.

AUMONT, Jacques. A imagem. Campinas, Papirus, 1993.

BAITELLO JUNIOR, Norval. A era da iconofagia. São Paulo, Hacker Editores, 2005.

. "Para que servem as imagens mediáticas? Os ambientes culturais da comunicação, as motivações da iconomania, a cultura da visualidade e suas funções”. Revista F@ro, n. 6. Valparaíso, Universidad de Playa Ancha, 2007.

BAUDRILLARD, Jean. À sombra das maiorias silenciosas: o fim do social e o surgimento das massas. São Paulo, Brasiliense, 2004, $1^{\text {a }}$ reimpressão.

. A troca simbólica e a morte. São Paulo, Edições Loyola, 1996.

. Forget Foucault. Los Angeles, Semiotext(e), 2007.

. Simulacros e simulação. Lisboa, Relógio d’Água, 1991.

BENJAMIM, Walter. Obras escolbidas: magia e técnica, arte e politica. São Paulo, Brasiliense, 1996. 
112 * Encanto e entorpecimento: um caminhar por entre imagens contemporâneas

BOORSTIN, Daniel J. The image or what happened to the american dream. Nova York, Atheneum, 1962.

BRUNER, Jerome. "Life as narrative". Social research, v. 71, n. 3, fall 2004.

CONSTANTINESCU, Valentin D. "The imperfect recognition: chaotic and recurrent mechanisms in high level vision”. In: LANGLEY, Pat \& SHAFTO, Michael G. Proceedings of the nineteenth annual conference of the cognitive science: august 7-10. Stanford, Stanford University, 1997, p.892.

COUCHOT, Edmond. "Da representação à simulação: evolução das técnicas e das artes da figuração". In: PARENTE, André (org.). Imagem máquina: a era das tecnologias do virtual. Rio de Janeiro, Editora 34, 1993, p. 37-48.

DEBORD, Guy. La société du spectable. Paris, Folio, 2008.

DELEUZE, Gilles. A imagem-tempo. São Paulo, Braziliense, 1990.

. Bergsonismo. São Paulo, Editora 34, 1999.

. Conversações. São Paulo, Editora 34, 2008, $7^{\mathrm{a}}$ reimpressão.

. Diferença e repetição. São Paulo, Graal Editora, 2006.

. Lógica do sentido, 4. ed. São Paulo, Perspectiva, 2007.

. "Pensamento nômade". In: MARTON, Scarlett (org.). Nietæsche hoje? São

Paulo, Brasiliense, 1985.

DELEUZE, Gilles \& GUATARRI, Félix. Mil platôs. São Paulo, Editora 34, 1995-1997, v. 1-5.

ECO, Umberto. Viagem na irrealidade cotidiana, 4. ed. Rio de Janeiro, Nova Fronteira, 1984.

FLUSSER, Vilém. Ensaio sobre a fotografia: para uma filosofia da técnica. Lisboa, Relógio d'Água, 1998.

. O universo das imagens técnicas. São Paulo, Annablume, 2008.

GERBASE, Carlos. "Flusser e Heidegger: as imagens técnicas na questão da técnica". Sessões do imaginário, v. 1, n. 6, julho 2001. 
HARVEY, David. Condição pós-moderna. 14. ed. Rio de Janeiro, Loyola, 1992.

HEIDEGGER, Martin. "A questão da técnica”. Cadernos de tradução. São Paulo, USP, 1997. . Introducão à metafísica, 4. ed. Rio de Janeiro, Tempo Brasileiro, 1999. - Que é uma coisa? Doutrina de Kant dos princípios transcendentais. Lisboa, Edições $70,1987$. Question concerning technology and other essays. New York, Harper, USA, 1977. . Ser e tempo. Petrópolis/Bragança Paulista, Vozes/Universitária São Francisco, 2006.

KAMPER, Dietmar. “Imagem”. In: WULF, Christoph. Cosmo, corpo, cultura: enciclopedia antropologica. Milão, Mondadori, 2002. Disponível para download em: <http://geccom.incubadora.fapesp. br/portal/referencias/textos/kamper/imagemkamper.pdf/view>. Acesso em 10 out. 2008.

"As máquinas são tão mortais como as pessoas. Uma tentativa de excluir o telemático do pensamento". Disponível em: <http://www.eca.usp.br/nucleos/filocom/traducao9.html>. Acesso em 25 set. 2008.

. "Imanência dos media e corporeidade transcendental. Oito postos de observação para um futuro medial”. Disponível em: <http://www.eca.usp.br/nucleos/filocom/ traducao8.html>. Acesso em 2 out. 2008.

. "O medial - o virtual - o telemático. O espírito de volta a uma corporeidade transcendental". Traduzido por Ciro Marcondes Filho. Disponível em: <http://www. eca.usp.br/nucleos/filocom/traducao7.html>. Acesso em 2 out. 2008.

KAMPER, Dietmar \& Baitello Junior, Norval. "Sobre o futuro da visibilidade". Seminário Internacional Imagem e Violência - Anais Eletrônicos. São Paulo, Centro Interdisciplinar de Semiótica da Cultura e da Mídia, 2001. Disponível em <http://www.cisc.org.br>. Acesso em 13 mai. 2008.

KOSSLYN, Stephen. Image in brain. Cambridge, The MIT Press, 1996.

KRACAUER, Siegfried. O ornamento da massa. São Paulo, Cosac Naify, 2009.

LEVY, PIERRI. Cibercultura. São Paulo, Editora 34, 1999. 
114 * Encanto e entorpecimento: um caminhar por entre imagens contemporâneas

. O que é o virtual? São Paulo, Editora 34, 1996.

LIPOVETSKY, Gilles. A sociedade da decep̧cão. Barueri, Manole, 2007.

LIPOVETSKY, Gilles \& CHARLES, Sebastien. Os tempos hipermodernos. São Paulo, Barcarolla, 2004.

LUHMANN, Niklas. A realidade dos meios de comunicação. São Paulo, Paulus, 2003.

MACHADO, Arlindo. Máquina e imaginário. São Paulo, Edusp, 1993.

MARCONDES FILHO, Ciro (org.). Dicionário da comunicação. São Paulo, Paulus, 2009.

Paulo, Paulus, 2004.

O escavador de silêncios; formas de construir e desconstruir sentidos na comunicação. São

- Princípio da razão durante. São Paulo, s/d.

. Superciber: a civilização místico tecnológica do século 21. São Paulo, Ática, 1997.

MARCORA, S. M.; STAIANO, W. \& MANNING, V. "Mental fatigue impairs physical performance in humans". Journal of applied physiology, 106. Bethesda, The american physiological society, 2009, p.857-64.

MERLEAU-PONTY, Maurice. Fenomenologia da percepção, 3. ed. São Paulo, Martins Fontes, 2006.

. O olho e o espirito. São Paulo, Cosac Naify, 2004.

. O visivel e o invisivel, 3. ed. São Paulo, Perspectiva, 2003.

MURZYN, Eva. "Do we only dream in colour? A comparison of reported dream colour in younger and older adults with different experiences of black and white media". Consciousness and cognition, v.17, 2008, p.1228-37.

NIETZSCHE, Friedrich. Crepúsculo dos ídolos ou como se filosofa com o martelo. São Paulo, Companhia das Letras, 2006.

PIAGET, Jean. A construção do real na criança. São Paulo, Ática, 1996. 
SANTAELLA, Lúcia. A percep̧cão: uma teoria semiótica. São Paulo: Experimento, 1993.

SCHOPENHAUER, Arthur. O mundo como vontade e como representação. São Paulo, Unesp, 2005.

SCHWITZGEBEL, Eric. "Do people still report dreaming in black and white? An attempt to replicate a questionnaire from 1942”. Perceptual and motor skills, 96, 2003, p.25-9. Disponível em: www.faculty.ucr.edu/ eschwitz/SchwitzPapers/MidRepl.pdf (acesso em 20.03.2010). 
